Paper presented at the 49th panel meeting of Economic Policy in Brussels.

\title{
The Effect of Employment Protection Legislation and Financial Market Imperfections on Investment: Evidence from a Firm-Level Panel of EU countries"
}

\author{
Federico Cingano (Bank of Italy), \\ Marco Leonardi (University of Milan and IZA), \\ Julian Messina (University of Girona, FEDEA and IZA) \\ Giovanni Pica (University of Salerno and CSEF)
}

\begin{abstract}
This paper analyzes the joint effect of EPL and financial market imperfections on investment, capital-labour substitution, labour productivity and job reallocation in a cross-country framework. In the spirit of Rajan and Zingales (1998) and Ciccone and Papaioannou (2006), we exploit variation in the need for reallocation at the sectoral and aggregate level to assess the average effect of EPL on firms' policies. Then, exploiting firm-level information we study if the effect of EPL is stronger in firms with lower levels of internal resources. We find that, on average, EPL reduces investment per worker, capital per worker and value added per worker in high reallocation sectors relative to low reallocation sectors. The reduction in the capital-labour ratio is less pronounced in firms with higher internal resources, suggesting that financial constraints exacerbate the negative effects of EPL on capital deepening.
\end{abstract}

\footnotetext{
*Email addresses: federico.cingano@bancaditalia.it, marco.leonardi@unimi.it, julian.messina@gmail.com, gpica@unisa.it
} 


\section{Introduction}

A large literature has established the importance of Employment Protection Legislation (EPL) in affecting job flows by reducing both workers' hiring and firing. Given that EPL represents an obstacle to the reallocation of resources, it is plausible that it also has a bearing on firms' investment decisions, on the capital-labour ratio and, eventually, on productivity. ${ }^{1}$ However, if EPL affects the pattern of investment and capital accumulation, a natural question - left so far unaddressed by the literature - concerns the impact of financial market imperfections on firms' response to more stringent employment protection provisions. The ability to adjust the capital stock or to adopt new technologies in the face of stricter EPL is in fact likely to be different in firms that have access to credit rather than financially constrained firms. Financially constrained firms may, for example, be unable to channel all their internal resources to productive investments when an increase in EPL raises labour costs and workers' bargaining power.

The purpose of this paper is to provide an empirical analysis of the effects of financing constraints on the adjustment of capital and labour in response to a change in EPL. We analyze the joint effect of EPL and financial market imperfections on investment, capital-labour substitution, labour productivity and job reallocation in a cross-country framework. In the spirit of Rajan and Zingales (1998) and Ciccone and Papaioannou (2006), we exploit variation in the need for reallocation at the sectoral and aggregate level to assess the average effect of EPL on firms' policies. Then, exploiting firm-level information on the availability of firms' internal resources we build different variables measuring firms' liquidity (operating cash-flow and net liquid assets) and study if the effect of EPL is stronger in firms with lower levels of internal resources that are therefore more likely to be financially constrained.

While there is a growing consensus in the empirical literature around the idea that employment protection regulations have important effects on employment adjustment, relatively little is known about the effects of employment protection on investment, capital deepening and labour productivity. Only recently these issues have received attention. Bassanini et al. (2009) look at the effect of EPL on job reallocation and TFP, using industry-level data (EUKLEMS) and find a negative effect of EPL on TFP. Autor et al. (2007) study the US case and, exploiting microdata, find that after an increase in EPL capital deepening increases and TFP declines.

\footnotetext{
${ }^{1}$ See Autor et al. (2007), Bassanini et al. (2009) and Cingano et al. (2008), discussed in the next section.
} 
This paper focuses on the role of financial market imperfections in shaping the response of firms to EPL. In our case, the use of firm-level data is crucial not only to control for firm-level heterogeneity but also - and most importantly - to achieve identification of the effect of interest, namely the interaction between firm availability of internal finance (financial market imperfections) and aggregate EPL (labor market frictions). To this aim, we exploit the availability of firm-level information from Amadeus data which is, to the best of our knowledge, the only available source of comparable firm-level information on balance sheets for countries for which we also have information on the nationwide level of EPL.

One reason for the lack of studies on the effects of EPL on investment and capital deepening is that, while theoretical models offer clear predictions regarding the effects of adjustment costs on job turnover, they provide no guidance on the expected effects of employment protection laws on capital investment, the capital-labour ratio and productivity. Moreover, both the theoretical and empirical literature are virtually silent on the interaction between financial markets and EPL, as discussed in the literature section.

In general the presence of dismissal costs will raise firms' adjustments costs. For this reason firms may have incentives to distort their production choices toward the more flexible input, thus substituting labour for capital. On the other hand, EPL may strengthen workers' bargaining power and exacerbate the "hold up" problem typical of investment decisions, resulting in less investment per worker. Hence, for a given technology, stringent firing costs might result in less capital per worker. However, when firms can adapt their technologies, higher EPL should favour the adoption of more capital-intensive technologies in the longer run. The final result on investment (and therefore the capital-labour ratio in the long run) is ambiguous and may therefore depend on workers' bargaining power and on the time span of the data.

EPL will also typically have an ambiguous effect on labour productivity: if dismissal protections induce firms to retain (some) unproductive workers, this will cause a decline in labour productivity, ceteris paribus. Offsetting this factor, employment protection not only protects workers, it also induces human capital accumulation and thus improves productivity (Belot et al. 2007). Furthermore firms may screen new hires more stringently when firing costs are high, leading to a favourable compositional shift in the productivity of the employed workforce.

The first part of this paper assesses the average effect of EPL on investment, the capital-labour ratio and labour productivity using Amadeus data. Following Rajan and Zingales (1998), our es- 
timates exploit both variation in the regulation across countries and the different relevance of the constraints imposed by regulation on firms in different sectors. We estimate the role of EPL looking at whether its impact is greater in industries where, in the absence of regulations, job reallocation would be higher. Exploiting the possibility to calculate job flows in different countries and industries from firm-level data, the "intrinsic" degree of volatility at the industry level is measured computing industry job reallocation in a hypothetical frictionless country with no employment regulation that faces world-average reallocation shocks (Ciccone and Papaioannou, 2006).

The analysis on firms' choices of capital and labour inputs shows that, on average, EPL reduces investment per worker, capital per worker and measured labour productivity (value added per worker) in high reallocation sectors relative to low reallocation sectors. The estimated effects are non-negligible. Reducing employment protection from the level prevailing in Greece in 1997 to that observed in Ireland in the same year (this shift correspond to the 90th to the 10th percentile of the country-by-year EPL distribution in our sample) increases capital intensity in industries at the 10th relative to industries at the 90 th percentile of the reallocation distribution by $12 \%$. The same exercise would imply an increase in investment per worker and in value added per worker in high relative to low turnover industries by $6.8 \%$ and $8.6 \%$, respectively. As most previous literature, we also find that EPL raises adjustment costs, as we find that EPL reduces job flows proportionately more in industries that require a higher level of reallocation.

Once the average effects of EPL are established, we put to test the main hypothesis of the paper, namely that financial market imperfections affect firms' responses to shocks in countries and sectors that are differently affected by EPL. We build two different firm-level measures of financial liquidity, one based on flows (cash-flow) and one based on stocks (net liquid assets). As the financial variables that measure liquidity vary at the firm level, we are able to control for any timeinvariant unobserved firm characteristics that may affect our dependent variables and are correlated with the level of firms' internal resources by using firms fixed effects, thus fully exploiting the firm-level dimension of the dataset.

We first show that the mere presence of an interaction term between EPL and firm-level measures of liquidity in the estimating equation does not alter the previous result that EPL has a negative significant impact on our dependent variables in high reallocation sectors relative to low reallocation sectors. However, if we do not control for unobserved heterogeneity, we also find that the negative effect of EPL on the capital-labour ratio is larger the higher the level of internal resources of the firm. This counterintuitive effect is likely driven by composition effects at the in- 
dustry level, as firms producing larger cash-flow not only have higher collateral and easier access to credit, but are also different along other dimensions, such as growth prospects and exporting propensity. In fact, when we move to a specification that includes firms fixed effects to control for firms' time-invariant unobserved characteristics and identify the effects of EPL from contrasts of within-firm changes, we find that EPL still reduces the capital-labour ratio, but less so in firms with higher internal resources (as measured either by cash-flow or by net liquid assets). This result seems to favour the interpretation that financial constraints exacerbate the negative effects of EPL on capital deepening. However, we take this finding as suggestive but only tentative as, when we turn to investments, we find only weak (if any) evidence of a differential effect of EPL on firms with different levels of liquid resources, a result possibly due to the lumpiness of the investment process, which deserves further exploration. Finally, neither value added per worker nor job reallocation are affected differentially by EPL in firms with different levels of internal resources.

\section{Policy Implications}

Our paper delivers potentially important policy implications. The debate on the role of EPL needs to consider not only the direct effect on employment flows, but also the indirect impact due to distorted investment incentives. Investment subsidies usually do not take into account the possible distortions induced by EPL and therefore may be excessive or insufficient.

Our findings potentially bear on the observed differences in the speed of structural change across developed countries (Rogerson, 2008): the distorted incentives for capital investment and their productivity effects may slow down the structural change from manufacturing industries towards services. Since most of the employment growth occurs in the service sector, these distortions may reduce employment growth, efficiency and income growth.

Regarding the interaction with financial markets, firms with low levels of liquid assets may have reduced ability to adjust their capital stock; the difficult substitution of capital for labour might lead to a decrease in the productivity of the employed workers. The obvious policy implication is that EPL is more harmful for liquidity constrained firms, or for sectors and countries where access to external credit is more difficult, and policies to alleviate the effects of EPL should be targeted there (or alternatively that financial constraints should be first softened for those same firms and sectors). However it is also true that EPL provides insurance to workers against firing. 
Hence, from the point of view of overall welfare, employment protection policies should be jointly evaluated with financial market frictions in the classic efficiency-equity trade-off.

The paper is structured as follows: Section 2 reviews the literature and the various mechanisms which link EPL to investment in capital and to labour productivity yielding ambiguous results for both. Section 3 illustrates the research method and discusses the identification strategy, while Section 4 introduces the data used for the study. Section 5 presents the basic results on the average effect of EPL while section 6 discusses the differential effects in financially sound vs. financially fragile firms. Section 7 provides some robustness checks and extends the analysis to examine the differential role of employment protection for temporary and permanent workers. Section 8 discusses the policy implications and concludes.

\section{Theoretical Considerations and Previous Empirical Literature}

In this section we review part of a very large literature on the economic impact of EPL, focussing on the expected effects on (1) investment and capital-labour substitution and (2) labour productivity. Models of labour demand in the presence of adjustment costs unambiguously predict a negative impact of firing restrictions on firing and hiring decisions (Bertola, 1990). The effects of EPL on job reallocation (the sum of firm's job creation and (absolute levels of) job destruction) have been extensively studied in the empirical literature, and consequently they are not the focus of this paper. It suffices to say that there is quite a consensus on the negative effects of EPL on job reallocation. Among the recent empirical papers, Autor et al. (2006) and Kugler and Pica (2008) study the impact of EPL on employment reallocation at the firm level in the US and Italy, respectively. At the cross-country level, Gomez-Salvador et al. (2004), Micco and Pages (2004) and Haltiwanger et al. (2006) among others exploit cross-country differences in EPL to establish a negative relationship between job flows and firing restrictions.

\subsection{EPL, investment and capital-labour substitution}

As argued in the introduction, there are theoretical reasons to expect an ambiguous effect of EPL on the capital labour ratio.

First, notice that firing costs are likely to push up labour costs even though labour may bear part of the burden via lower wages. For instance, severance payments and notice periods are a transfer from the firm to the worker, and it is likely that workers at least partially compensate firms for this transfer (Leonardi and Pica, 2008). Also the tax component of firing costs does not 
necessarily raise labour costs one to one in countries with an experience rating scheme, as the receipts can be used to compensate firms via lower unemployment insurance premiums (as in Blanchard and Tirole, 2004).

While in perfect labour markets an increase in the cost of labour will imply substitution of labour with more capital, in models with wage bargaining between workers and firms there may be the opposite effect. When there is wage bargaining, workers will use the protection of EPL to claim higher wages (Bentolila and Dolado 1994, and Garibaldi and Violante 2005). EPL will strengthen the outside option of workers and worsen the outside option of firms in the wage bargain. As a result, EPL may result in a higher bargained wage.

When EPL pushes up labour costs, because it is an actual cost or because the government or workers do not fully compensate firms for their transfers, firms will reduce their hiring until expected costs are in line with expected profits again and/or will reduce their investment. In models with capital investment an increase of EPL and of the bargained wage gives rise to a "hold up" problem.

If workers and employers meet in a random, costly process, some investment decisions have to be taken after a worker (of a given skill level) has been located and hired: and since replacing that worker would be costly, the worker can in general try and bargain for higher wages if investment increases the job's productivity. The employer is 'held up' by the worker, who lowers the employer's private returns to investment and therefore his/her incentive to invest (Bertola 1994).

A different case arises in the longer run when firms are not held up by irreversible investments and technology adoption becomes an issue. More EPL means that labour is more costly and when adopting new technologies firms will choose more capital intensive technologies (see among others Caballero and Hammour, 1998, Alesina and Zeira, 2006 and Koeniger and Leonardi, 2007).

\subsection{EPL and labour productivity}

The impact of EPL on labour productivity is also, in principle, ambiguous. On the one side, EPL hampers the reallocation of workers and jobs across industries and firms. Therefore, when the importance of reallocation for productivity is large, productivity falls. On the other side, EPL may have a positive effect on productivity via specific investments and learning-by-doing. Mixed results are instead found in studies that focus on partial EPL reform via the introduction of tem- 
porary contracts. A screening period of temporary contracts may lead to better matches, increasing productivity, but the incentives for specific investments and the period for learning-by-doing may fall, reducing productivity.

a) Considerations suggesting a negative effect of EPL on productivity

More stringent EPL may reduce productivity because of 'sclerosis' in the production structure (i.e. EPL is an obstacle to reallocation of activity across industries and to risk-taking), because higher skill losses during longer periods of unemployment, or because employees, shielded from a possible layoff due to firing costs, tend to shirk on the job more often.

As to reallocation and risk-taking, according to Nickell and Layard (1999) 'there seems to be no evidence that either stricter labour standards or employment protection lowers productivity growth rates'. For their empirical analysis, Nickell and Layard use aggregate data for 20 OECD countries observed in the period 1976-1992. In some specifications they actually find a positive effect of EPL on the growth rate of labour productivity but this effect disappears in other specifications.

Other papers emphasize the effects of EPL on reallocation via entry and exit of firms. Hopenhayn and Rogerson (1993) show how the distortion induced by firing restrictions pushes firms to use resources less efficiently. As a result, employment levels adjust at a lower speed and productivity is reduced. Poschke (2007) emphasises the role of firing costs in the selection of the most efficient firms and the exit decision of low productivity firms, if exiting firms cannot avoid paying them. Samaniego (2006) claims that firing restrictions are more costly in industries characterised by rapid technological change such as ICT. Countries where regulations are more stringent will therefore tend to specialise in industries with a slow rate of technical change.

Some studies emphasize the obstacle of EPL to undertake risky activities. Bartelsman and Hinloopen (2005) find that EPL has a significant negative effect on investments in ICT. They run regressions using data for 13 OECD countries for the period 1991-2000. They conclude that EPL reduces the incentive for firms to invest in innovative activities with high returns and a high risk of failure because firms want to avoid the risk of paying high firing costs. Saint-Paul (2002) argues that high firing costs may induce secondary innovation that improves existing products rather than introducing riskier ones. 
Ichino and Riphahn (2005) and Riphahn (2005) claim that layoff protection (or the lack thereof during the probation period) might also affect productivity by reducing worker effort because there is less threat of layoff in response to poor work performance or absenteeism.

b) Considerations suggesting a positive effect of EPL on productivity

More stringent EPL may also promote specific investments and result in more learning-by-doing, which may increase productivity. EPL also provides insurance against uninsurable labour income risk, and this may allow for better search of jobs.

Belot et al. (2007) propose a framework where, by providing additional job security, protection against dismissal may increase workers' incentives to invest in firm-specific human capital, therefore enhancing productivity. On the other hand, higher firing costs raise separation costs, increase the bargaining power of the worker, and thereby raise wages. Only at low levels of employment protection is an increase in EPL beneficial to productivity-growth, and the positive effects of employment protection are larger in sectors where firm-specific skills matter more.

Wasmer (2006) suggests that by inducing substitution of specific for general skills, firing restrictions may have a negative effect on productivity when workers need to be reallocated across industries and industry-specific skills become useless. Lagos (2006) claims that if stringent EPL raises reservation wages, average productivity can increase simply because firms become more selective and less productive matches are not realised.

Bertola (2004) shows that the additional insurance via severance pay may also result in a productivity gain in the spirit of Acemoglu and Shimer (1999), making workers more willing to leave their low-productive job to look for a more productive one.

The empirical part of most of the papers reviewed, if present at all, is based on cross-country regressions on aggregate outcomes. However, this approach potentially suffers from well-known severe problems. First of all, reverse causality: the strictness of EPL may depend on labour market conditions. Second, omitted variables may bias the results: EPL may pick up the effect of other factors unobserved by the econometrician that drive the cross-country differences in labour market performance. Third, most studies focus on overall EPL, without distinguishing between EPL provisions for fixed-term and permanent contracts.

As far as we know, very few studies go beyond country-level data. Scarpetta et al. (2002) analyse the effects of EPL and centralized bargaining on firm productivity and firm dynamics using harmonized data for 17 manufacturing industries in 18 countries, over the period 1984-1998. They 
find that strict EPL has a significant negative impact on productivity only in countries with an intermediate degree of centralisation/coordination in wage bargaining.

Autor et al. (2007) study the impact of adoption of wrongful-discharge protection norms in the US, using cross-state differences in the timing of adoption. Exploiting microdata, they find that capital deepening is increased while TFP is reduced. Quantitatively, they calculate a drop in productivity, with an average elasticity in the order of 0.03 to 0.04 . Similar findings are provided by Cingano et al. (2008) using Italian data to examine a 1990 reform that raised dismissal costs for firms with fewer than 15 employees only.

Micco and Pagés (2004) analyse the difference in the effects of EPL across sectors within a certain country. They argue that EPL is more binding in sectors that are more susceptible to technological and demand shocks. They use data for the manufacturing sector for 18 countries during the 1980s and 1990s, and find a negative relationship between layoff costs and the level of labour productivity especially in those sectors with higher needs for flexibility.

The paper closest to ours is Bassanini et al. (2009), which uses sectoral harmonized data from EUKLEMS for 17 industries in 18 industrial economies over the past two decades. They consider EPL together with other labour market institutions and the extent to which EPL is binding in particular industries. They find a negative effect of EPL on total factor productivity (TFP) and conclude that reforms of overly strict dismissal regulation in many OECD countries can be justified on the grounds of fostering TFP growth.

\section{Empirical Framework}

In order to describe the identification strategy that allows us to estimate the joint effect of labour and financial market imperfections, we proceed in two steps. In section 3.1 we describe the identification strategy of EPL neglecting credit markets, and in section 3.2 we extend our empirical framework to allow for the presence of (imperfect) capital markets.

\subsection{Identification of the average effect of EPL on firm-level outcomes}

Our empirical strategy relies on a well-established approach developed in the finance literature by Rajan and Zingales (1998) and recently adopted in labour studies (see Micco et al. 2004, Fonseca and Utrero, 2006, Haltiwanger et al. 2006 and Bassanini et al., 2009) to estimate the impact of some country characteristic (often, measures of regulation) on economic performance accounting 
for geographical- and technological-specific time-invariant unobservables. The basic idea underlying the approach is to exploit the fact that while the amount of regulation is given for all firms within a country, its impact could be different if, due to technological characteristics or to the incidence of aggregate shocks, firms do differ as to the frequency or amount of required labour reallocation. In this case, the importance of employment protection legislation can be inferred by looking at whether firms requiring more reallocation see a better performance in countries with less restrictive legislation.

The main problem with this approach is recovering a plausible measure of employment reallocation requirements. Job flows are in fact not customarily included among official statistics and even if they were observable at the firm or industry level, they would likely reflect idiosyncratic components endogenous to the level of EPL in each country. This implies they would in general not just reflect the amount of reallocation of a frictionless environment, where the extent of yearly flows only responds to, say, technological firm or industry differences. Hence, using actual labour reallocation is likely to yield biased estimates of the impact of EPL on performance. Following the influential study of Rajan and Zingales (1998) on financial development, one popular approach to this problem is to proxy for firms' characteristics in the absence of distortions using data from a flexible market economy. For example, Micco and Pages (2004), Haltiwanger et al. (2006) and Bassanini et al. (2009) use reallocation figures computed for US industries. Their underlying assumption is that such baseline should proxy for the technological and market driven employment reallocation across industries in the absence of policy-induced costs of adjustment.

Applying this approach implies estimating the standard differences-in-differences specification of studies exploiting cross-country cross-industry data:

$$
Y_{i j t}^{c}=\left(E_{t}^{c} \times \text { BenchFlow }_{j}\right) \delta+E_{t}^{c} \varphi+X_{i j t}^{c} \gamma+\mu_{t}+\mu_{j}+\mu^{c}+D+\varepsilon_{i j t}^{c}
$$

where $Y_{i j t}^{c}$ is the outcome variable of firm $i$ in country $c$, industry $j$ at time $t ; E_{t}^{c}$ is a countryvarying index of employment protection legislation; BenchFlow $w_{j}$ is the extent of "intrinsic" job reallocation in sector $j$ (below we describe the different proxies used in this paper). The various specifications encompass different sets of year-, industry- and country- effects (respectively $\mu_{t}, \mu_{j}, \mu^{c}$ ) and their interactions $D$. The matrix $X_{i j t}^{c}$ includes firm-level control variables and $\varepsilon_{i j t}^{c}$ is the residual. We take care of the intra-cluster correlation of standard errors. 
Equation (1) allows to estimate the average effect of EPL exploiting variability at the countrysector-time level in the relationship between employment legislation and outcomes. At this stage, we do not include firms fixed effects because they would wash away all the industry by country variation making the identification of the variable of interest (Exbenchflow) rely only on the (limited) time variation of the EPL index.

The coefficient $\delta$ in equation (1) captures the effect of employment regulation on the variable of interest. One way to interpret $\delta$ is thinking of the average difference in the variable of interest $Y$ between two industries characterized by high and low reallocation flows (say, corresponding to the $10^{\text {th }}$ and $90^{\text {th }}$ percentile of the observed distribution, respectively). Then estimates of $\delta$ in equation (1) can be thought of as the implied change in such differential as employment protection is increased by an arbitrary amount (say, equivalent to the $10^{\text {th }}-90^{\text {th }}$ difference observed across countries).

Following the standard benchmark-country approach would require proxying the sectoral intrinsic need for job reallocation using data from the most flexible market economy available (the US or, in our sample, the UK). The appropriateness of the benchmark-country approach can however be questioned along two dimensions. First, the validity of the benchmark hinges on the representativeness of the industry in the benchmark country, within the set of countries covered in the sample. Even if US reallocation rates in a given industry are a good proxy of the intrinsic needs of reallocation in that sector, it might be the case that within sector heterogeneity across countries limits the comparative exercise. An example illustrates well this problem. If the researcher is using benchmark flows measures at the 2-digit industry level of aggregation, the reallocation in sector 35 "Manufacture of Transport Equipment" in the US, would serve as benchmark reallocation for the remaining countries in the sample. However, going finer in the industry classification one finds that industry 35 is composed, among others, of sub-sectors 3511 "Building and repairing ships and boats", 3530, "Manufacture of aircraft and spacecraft" and 3542 "Manufacture of bicycles". The benchmarking requires that either intrinsic needs of reallocation in the three sub-sectors are similar, or that the average within sector industry mix in every country in the sample is well proxied by the average industry mix in the US. A finer level of aggregation of the benchmark would limit this problem.

Second, the benchmark-country approach has been questioned for representing a measure of short- rather than long-term industry-differences (Fisman and Love, 2003). This would imply in our case that the benchmark constitutes a noisy proxy of frictionless (or technological) industry 
reallocation requirements. In a recent paper, Ciccone and Papaioannou (2006) have formalized this problem by showing that if the benchmark reflects, among other factors, idiosyncratic shocks, then the measurement error stemming from country-benchmarking can induce both upward and downward biases in the estimates of $\delta$ in (1). In our case, if employment reallocation across industries in the benchmark country correlates more closely with reallocation in low-EPL countries than in high-EPL countries, then one might find significant effects of regulation even if there were not.

To circumvent the problem Ciccone and Papaioannou $(2006,2007)$ proposed a methodology to construct a world-average benchmark measure not reflecting idiosyncratic factors specific to a country or regulatory environment. Exploiting the availability of industry (or firm-) specific figures of job reallocation $J R_{j c}$, such a measure can be obtained in our case regressing job reallocation measured at a detailed industry level on country dummies interacted with time dummies, industry dummies and industry dummies interacted with country-level EPL:

$$
J R_{j t}^{c}=\alpha_{j}+\lambda_{t}^{c}+\theta_{j} E_{t}^{c}+v_{j t}^{c}
$$

where the interaction term $\theta_{j} \times E_{t}^{c}$ allows to absorb the marginal effect of employment protection on job reallocation in each industry $j$, and $\lambda_{t}^{c}$ accounts for time-varying differences at the country level. Hence $\hat{\alpha}_{j}$ captures the extent of industry job reallocation in a country not subject to firing restrictions (we are controlling for EPL), which is subject to world average supply and demand shocks. This is the measure of frictionless sectoral reallocation $\left(\right.$ BenchFlow $\left._{j}=\hat{\alpha}_{j}\right)$ in equation (1) that will be used in the paper. Hence, we collapse our firm level data (described below) at country-industry-year cells and run a regression following equation (2) in order to extract the $\hat{\alpha}_{j}$ 's. The job reallocation rate is defined, following Davis and Haltiwanger (1990), as

$$
J R_{j t}^{c}=\sum_{i \in j, c} 2 \frac{\left|e_{i j t}^{c}-e_{j i t-1}^{c}\right|}{e_{i j t}^{c}+e_{i j t-1}^{c}}
$$

where subscripts are defined as above. In order to preserve a minimal level of representativeness in each cell, we drop all cells where job reallocation was computed for less than 10 firms.

While the Ciccone-Papaioannou methodology allows avoiding country-specific idiosyncrasies, its main limitation is that, since no country in our sample has zero EPL, it computes trustworthy frictionless rates only under the assumption that out-of-sample predictions are reliable. For this 
reason, we check the robustness of this approach, by using as an alternative benchmark the sectoral job reallocation rates (averaged over time) of the country with the lowest level of EPL in our sample. ${ }^{2}$ Comparing the results obtained using the two alternative measures is interesting to assess to what extent widely used benchmark-country proxies reflect idiosyncratic shocks.

Figure 1 below depicts the relationship between actual job reallocation in the UK, the country with the lowest level of EPL in our sample, measured at the 4-digit industry level (more than 400 sectors) with the measure obtained following equation (2). The picture shows that the actual UK job reallocation rate and the Ciccone-Papaioannou (2007) "frictionless" job reallocation measure are strongly positively related. The slope of the linear fit (dotted line) is positive and significant. Although the relationship between both measures is positive and significant, it is different from a hypothetical $45 \%$ line, suggesting that UK job flows are a mix of world average and idiosyncratic needs for reallocation.

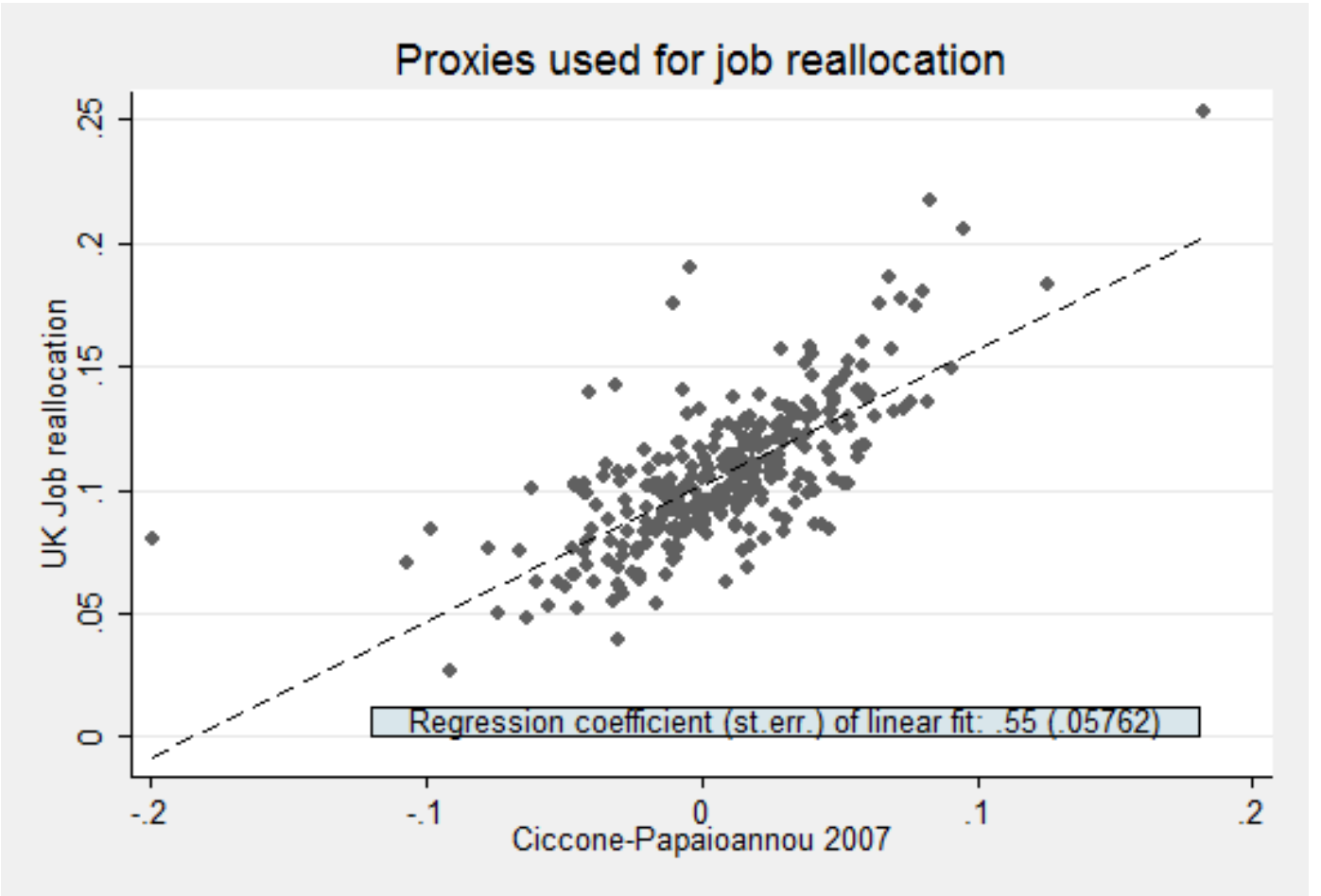

Figure 1. Job reallocation in UK and world-average Ciccone-Papaioannou (2007) measure.

\footnotetext{
2 One can argue that the frictionless measure using only within sample countries has an endogeneity problem and that, insofar as the driving variable appears to be EPL on regular contracts, benchmarks based on layoffs would be more pertinent than benchmarks based on turnover (for example services are notoriously high turnover but low layoff industries). To address this problem we also used the sectoral layoff rates from the US (a country external to the sample) taken from Bassanini et al. (2009) as an alternative benchmark. Specifications based on this measure give insignificant but qualitatively similar results. This is likely due to the fact that this measure is available only for 16 sector, rather than for the more than 400 sectors implied by the Amadeus 4-digit disaggregation.
} 
Finally, notice that there might be an issue of endogeneity of regulations. It is likely, for example, that countries that experience high turnover rates have a high demand for strict employment protection legislation. Alternatively, countries with low employment creation may tend to protect existing jobs. An attempt to address the problem using instrumental variables can be found in Bassanini et al. (2009). Our approach allows us to use country (by time) and sector fixed effects to control for all observable and unobservable country and sector characteristics. In particular, it allows to control for differences in country and sector output volatility, thus alleviating the potential problem of endogeneity of regulations present in cross-country regressions. In fact to claim endogeneity in our approach, one would have to argue that across countries a high level of turnover or low job creation in some sectors determines the level of employment protection in the whole country.

\subsection{Identification of the joint effect of EPL and financial market imperfections}

As explained in the introduction, the main contribution of our analysis lies in the study of the joint effect of EPL (labour market frictions) and financial constraints on the capital-labour ratio, investment and labour productivity. We therefore relate to the large literature that looks at the determinants of capital investment and finds access to the credit market to be one of the important factors affecting investment.

Most empirical studies of investment and financing constraints, in the tradition of Fazzari, Hubbard and Petersen (1988) typically regress a measure of investment on a measure of investment opportunities (Tobin's $q$ ) as well as a measure of cash flow, i.e. they estimate the sensitivity of investment to cash flow conditional on $q$. These empirical specifications imply that, in the absence of financing constraints, investment is likely to be subject to adjustment costs that prevent the capital stock adjusting continuously to maintain equality between the marginal revenue product and the user cost of capital. In the absence of financial frictions, Tobin's $q$ is a sufficient statistic for investment opportunities, which means that nothing but $q$ should matter in investment equations. A positive correlation between investment and liquidity, conditional on $q$, is therefore taken as evidence of the presence of financial market imperfections that prevent positive net present value projects to be financed, possibly because of moral hazard problems.

In this paper, differently, we study the joint effect of EPL and financial constraints on the outcome variables i.e. the differential effect of EPL on all outcome variables for financially con- 
strained firms. The impact of credit and labour market imperfections on investment has been theoretically analyzed in Rendón (2004) and in Wasmer and Weil (2004), who showed that job creation is limited by financing constraints even in the presence of a flexible labour market.

There are not many papers that investigate empirically the joint influence of imperfect financial and labour markets on investment, with the exception of Calcagnini and Giombini (2008). Their results show a negative correlation between EPL levels and investments. In particular they find that firms facing negative shocks see their financial constraints worsening in countries with greater labour market rigidities.

The interaction of financial frictions and EPL is evaluated in our cross-country panel data framework exploiting the interaction between labour and financial market imperfections at the firm-level. To this purpose we augment our baseline specification (1) with the operating cashflow of firm $i$ at any observed year $t$-1. We take the lagged value of cash-flow in order to make sure that we measure liquidity before investments are made. Otherwise, reverse causality may be at work since high investments may generate low levels of liquidity. We interact cash-flow with EPL and Benchflows separately, and with their interaction EPL $\times$ Benchflows, as described in the following equation:

$$
\begin{aligned}
Y_{i j t}^{c}= & \left(E_{t}^{c} \times \text { BenchFlow }_{j}\right) \delta_{0}+\left(E_{t}^{c} \times C F_{i j t-1}^{c}\right) \delta_{1}+\left(C F_{i j t-1}^{c} \times \text { BenchFlow }_{j}\right) \delta_{2}+ \\
& +\left(E_{t}^{c} \times C F_{i j t-1}^{c} \times \text { BenchFlow }_{j}\right) \delta_{3}+E_{t}^{c} \phi_{0}+C F_{i j t-1}^{c} \phi_{1}+\beta R O A_{i j t-1}+\mu_{i}+D+\varepsilon_{i j t}^{c}
\end{aligned}
$$

where

$$
C F_{i j t-1}^{c}=\frac{\text { Cash Flow }_{i j t-1}^{c}}{\text { Fixed Assets } \text { sijt-2 }^{c}}
$$

and $D$ is a vector of dummy variables including country by year interactions. The coefficient $\delta_{3}$ of third level interaction term $\left(E_{t}^{c} \times C F_{i j t-1}^{c} \times\right.$ BenchFlow $\left._{j}\right)$ captures the effect of a change in EPL on investment - and on the other dependent variables - in firms with different levels of internal resources in sectors with different volatilities of employment. If higher levels of internal resources facilitate capital deepening (as in presence of credit constraints) then this interaction term should positively enter the investment per worker and $K / L$ equations.

Since computing Tobin's $q$ requires information on the market value of the firm and the vast majority of firms in our sample are unlisted, in this work we will measure investment opportunities with the rate of Return on Assets (ROA in equation 3). 
Note that our specifications now include firm level fixed effects, since the variable of interest in this case is not an aggregate variable as in the previous specification, but varies over time within firms. In this context, it becomes crucial to control for any unobserved factor that remains constant within firms and might be correlated with the cash flow measure. One may in fact argue that firms able to produce a higher cash-flow have (1) easier access to credit but (2) are also typically larger and (3) behave differently along many (unobservable) dimensions. To the extent that these unobserved factors are time invariant, they are accounted for by firms fixed effects.

To test the robustness of our results we use two measures of internal resources. The first is operating cash-flow. The second, following Cleary, Povel and Raith (2005), is a stock measure of liquidity called net liquid assets, described in detail in the robustness section.

\section{Data description}

Our main data source is Amadeus, a firm level data set collected by the Bureau van Dijk (BvD) containing balance-sheet information of European firms. ${ }^{3}$ The information is gathered by specialized national service providers and is homogenised applying uniform formats in order to allow accurate cross-country comparisons. We used the largest version of Amadeus in its 2006 DVD format, which covers firms of all sizes for the period 1994-2005. However, the coverage prior to 1997 is relatively limited. Similarly, EPL data is only available up to 2003. Hence, we restrict the analysis to the period 1997-2003, but robustness checks adding these additional years are provided in Section 7. The 14 countries under study are: Belgium, the Czeck Republic, Denmark, Finland, France, Germany, Greece, Italy, the Netherlands, Poland, Portugal, Spain, Sweden and the United Kingdom. ${ }^{4}$

The limitations of this firm-level dataset are well-known. First, what the data company is able to report depends on how demanding the accounting standards of a country are and which firms indeed report. Therefore, without any doubt, the sample is biased toward countries with more de-

3 See Messina and Vallanti (2007) and Konings et al. (2005) for descriptions of Amadeus in different research contexts. Giannangeli and Gómez-Salvador (2008) use Amadeus in an study of the sources of growth in manufacturing productivity in five European countries.

${ }^{4}$ We tried to cover all countries in Amadeus for which EPL data from the OECD was available. Austria and Germany constitute special cases in Amadeus. Most firms in these two countries have limited information on their balance sheets, including employment and very few financial items. After data cleaning, this results in insufficient observations in the case of Austria for most of the specifications. Hence, Austria is dropped from the analysis. Slovakia, Ireland and Hungary were also dropped due to small samples. There are very few German firms too in the sample, but sufficient to be present in most country, year and sector cells. The analysis in the paper includes Germany, and robustness checks excluding specific countries are discussed at the end of the paper. 
manding accounting standards and more transparent firms. If anything, this sample selection bias should make it harder to find a significant impact of financial market imperfections on firms' response to stricter EPL. Moreover, in any given country, the sample may not be representative of the underlying population. In principle this problem could be addressed by cross-checking our results (at least those not involving firm-specific measures among the variables of interest) against estimates obtained running the corresponding regressions at a more aggregate level using information from country-industry datasets. In practice, this strategy is largely undermined by the significant lack of data on investment and capital stocks at the industry level. For example, the increasingly used Euklems dataset assembling industry-level accounts for EU members at a 2-digit level of disaggregation lacks information on capital stock for countries as France, Spain and Belgium, which constitute a relevant share of observations in our sample. Unfortunately, the OECD Stan dataset, a possible alternative source of data even though with a coarser industry breakdown, also present a significant fraction of missing values as regards the stock of capital. To get reassured that Amadeus firms does not completely misrepresent the population distribution we aggregated our data to the corresponding Euklems industry-level breakdown and computed correlations between country-industry shares of employment and value added in the two datasets (such information is available in Euklems for all countries in our sample). In 2003, the correlation is 0.44 in the case of employment and 0.35 in the case of value added.

Despite the above described limitations the use of Amadeus is becoming widespread in the economic profession for several reasons. First, the reclassification of the balance sheets appears reliable, since no attempt is made to reconstruct items that are missing from the original balance sheets or difficult to reconstruct. In fact, many variables are missing, especially for firms incorporated in countries where accounting practices are less transparent. Another important advantage of Amadeus is that most of the firms included in the data set are private, allowing to focus on a sample that is more representative than the listed companies typically analysed in studies on credit markets (see Rajan and Zingales, 1995 and Boot, et al., 2001). This naturally entails some shortcomings given that the information available for private firms is less detailed. Moreover, since private firms are not traded, only book values are available and it is not possible to evaluate the market values of debt ratios, which would provide useful additional information. However, this shortcoming are not likely to hamper the analysis because previous studies (Rajan and Zingales, 1995 and Boot, et al., 2001) do not find any significant differences in factors correlated with debt to book and market capital. 
For the aims of this paper the advantages of looking at a panel of balance sheet data for firms in different countries largely prevail over the disadvantages. First and foremost, the availability of balance sheet data allows us to study whether and to what extent labour market regulation interacts with financial constraints when firms react to aggregate or idiosyncratic shocks. This analysis simply cannot be performed on sectoral data. ${ }^{5}$ Second, even when focusing on the average effects of employment protection, the use of firm-level data is advisable, as one can account for industry and country specific unobserved characteristics in ways that studies based on aggregate data are unable to correct for. This makes our study less subject to miss-specification and omitted variable biases. Finally, the firm-level data is classified at a very detailed industry dimension (4-digit NACE classification). The possibility of constructing the benchmark "frictionless" job flow measure at such a refined level of aggregation helps us limiting possible problems of comparability of industries discussed above.

\subsection{Descriptive Statistics}

Figure 2 reports the average values of our variables of interest by country, thus giving a visual representation of the descriptive statistics by country presented in Table 1 . The upper left panel reports both EPL levels (averages in 1997-2003) and changes (from 1997 to 2003) and shows that the United Kingdom displays the lowest level of EPL in our sample period while Portugal displays the highest. It is noteworthy (and also well-known) that EPL varies very little over time. The upper left panel of Figure 2 shows that most countries display very little or no variation of EPL over time, with the exception of Italy. Table 2, which reports descriptive statistics by year, shows that average EPL ranges from 2.44 and 2.56 over our sample period. This is why we do not include firms' FE in the estimation of equation (1). The remaining panels of Figure 2 show the average levels of capital per worker, value added per worker and investment per worker. Germany and Belgium exhibit the highest values of all of them (except $I / L$, where Poland ranks higher than Belgium) while the United Kingdom ranks very low both for investment and for capital.

However, the most interesting statistics are perhaps those presented in table 1, where we show the average levels of job reallocation, capital per worker, value added per worker and investment per worker in high and low job reallocation sectors and high and low EPL countries, where we take as low (high) job reallocation sectors those below (above) the $25^{\text {th }}\left(75^{\text {th }}\right)$ percentile of the distri-

5 Few recent papers addressed a similar issue in a totally different framework, i.e. studying the determinants of corporate control (Atanassov and Kim 2008, Pagano and Volpin 2005, Bozcaya and Kerr 2008). 
bution of the frictionless job reallocation and as low (high) EPL countries those below (above) the $25^{\text {th }}\left(75^{\text {th }}\right)$ percentile of the distribution of EPL. The list of the low- and high- reallocation sectors is in the note to the table.

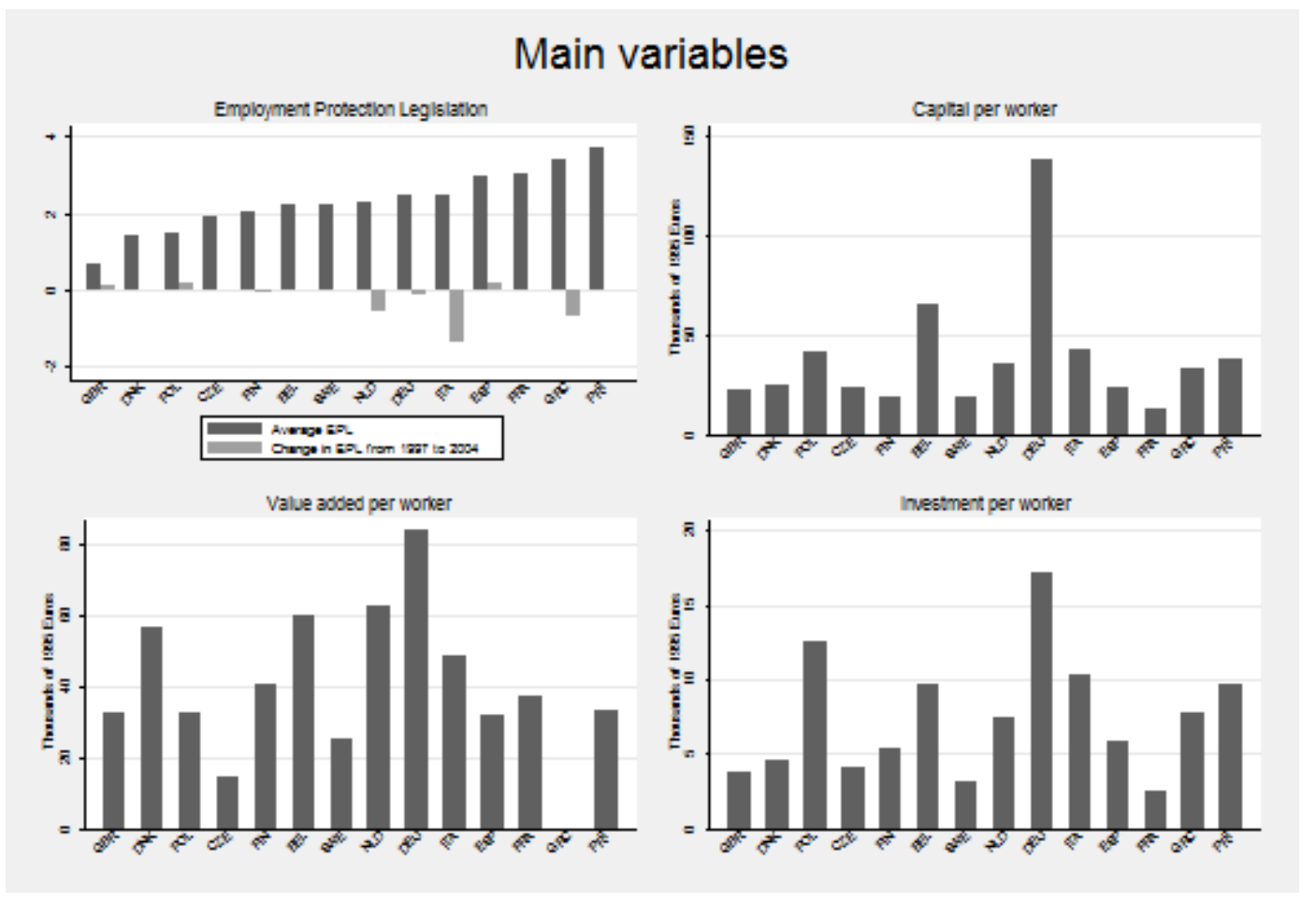

Figure 2. Summary Statistics by Country

We perform an unconditional diff-in-diff exercise that mimics our identification strategy in equation (1). The results of this exercise, while allowing a better understanding of our identification strategy, should be taken with caution because (1) the regression exercise is based on a continuous treatment (i.e. in the regressions we will not arbitrarily divide sectors into two groups but rather use the Ciccone-Papaioannou (2007) continuous measure of intrinsic job reallocation) and (2) because of the presence of aggregate confounding factors. Notice, for example, that in our data Job Reallocation (first row) is higher in high EPL countries, both in sectors classified as displaying low and high (intrinsic) needs of job reallocation. This suggests the existence of a positive correlation between employment legislation and turnover at the aggregate level, as in the case in which countries tend to have higher levels of protection in response to exogenously induced increases in flows (e.g. a deep restructuring of the productive structure). That is one of the reasons why our analysis will look at within-country effects of EPL exploiting a diff-in-diff approach as in Rajan and Zingales (1998). Moreover, it suggests that using country-specific reallo- 
cation rates might induce severe biases because reallocation might responds to country-specific legislation. Our attempt to construct a world-average benchmark measure not reflecting idiosyncratic factors specific to a country or regulatory environment aims at addressing this issue. Overall, table 3 shows a negative unconditional effect of EPL on job reallocation and value added per worker, while the industry-level differential in capital and investment intensities seem to increase. As we will see, the conditional continuous-treatment version of this approach points to substantially different results as far as investment and capital per worker are concerned.

\section{Results: average effect of EPL}

In this section we document the relevance of employment regulations exploiting differences in sector characteristics to implement a difference-in-differences estimation method. We first look at the effects on capital and investment normalized by unit of labour (section 5.1). Then we look at the effects on labour productivity and for comparison with previous studies we assess whether employment protection legislation affects the level of job reallocation (section 5.2). In section 6 we move to the analysis of the role of internal resources in firms responses to stricter firing restrictions.

\subsection{Capital and investment per worker}

The five columns of Table 2 show that EPL reduces the capital-labour ratio in firms operating in the most affected sectors. The first column includes country, year and sector dummies (438 four digits dummies) to absorb institutional, technological and time specific effects. In the second column we include industry-by-time dummies to control for differential trends by industry in the outcome variable. For example some industries may experience faster (e.g. the computer industry) or lower-than-average (e.g. manufacturing) capital adjustment or job reallocation or productivity growth in all countries. In the same column we also include country-by-time dummies to control for all country-specific time-varying characteristics (for example all national-level institutions) which have the same effects across industries. Notice that this set of dummies absorbs the main effect of EPL, as this variable only varies by country and time. ${ }^{6}$

In table 2 we find strong adverse effects of employment protection on capital-labour ratios. The coefficient on the interaction is strongly significant and in the neighbourhood of -0.40 . In order to

\footnotetext{
${ }^{6}$ Note that while we study firm-level outcomes, our variable of interest in equation (1), the interaction term $E P L \times$ benchflows, varies at the four-digit industry level in 14 countries and 7 years. We take care of the intra-cluster correlation of standard errors likely to arise in all the specifications discussed.
} 
get an idea of their magnitude, consider the ratio of capital-intensity between industry 1561 "Manufacture of grain mills product" and industry 2955 "Manufacture of machinery for paper or paperboard production", the two industries we estimate at the $10^{\text {th }}$ and $90^{\text {th }}$ percentile of the capital-labour ratios distribution. Then our estimates imply that reducing employment protection from the level Greece in 1997 to that in Ireland the same year (this shift correspond to the $90^{\text {th }}$ to the $10^{\text {th }}$ percentile of the country-by-year EPL distribution in our sample) would increase such ratio by $12 \%$.

In a first attempt to control for heterogeneity, the third column includes firm-level controls (firmsize, exports and number of subsidiaries). ${ }^{7}$ In the fourth column we aggregate Amadeus data at the industry level and we run regressions at the industry level to ease comparison with results obtained by previous literature using EUKLEMS data (Bassanini et al., 2009). In both columns 3 and 4 the results are qualitatively unchanged with respect to the first two columns. The last column of tables 2 uses sectoral job turnover in the UK as benchmark to test the robustness of our frictionless measure. The results are qualitatively similar and will be further commented upon in the robustness section.

We then turn to examine the effect of employment protection legislation on investment. We report the results in Table 3 for investment normalized by units of labour, as this is the relevant variable in models of hold-up.

Results in columns 1 to 5 indicate a significant negative effect of EPL on investment over labour units. The coefficient in columns 1, 2 and 3 lies around -0.2 and is strongly significant. To gauge the magnitude of the effects, we repeat the thought experiment of decreasing employment protection legislation from the $90^{\text {th }}$ to the $10^{\text {th }}$ percentile of the observed distribution. This implies an increase of $6.8 \%$ in the average $I / L$ ratio between two industries at the $10^{\text {th }}$ and $90^{\text {th }}$ percentile of the observed distribution.

Negative results on the capital-labour ratio are consistent with results on $I / L$ that show that investment is actually falling relative to the units of labour employed (table 3). The overall picture shows a reduction in capital investment (relative to labour) in consequence of an increase in EPL as predicted from "hold up" theories (see section 2).

\footnotetext{
${ }^{7}$ Exports and number of subsidiaries display non missing values only for a relatively limited number of observations. As for these variables the non missing values are always strictly positive, it is plausible to interpret them as zeros. We do so and check the robustness of this assumption adding one additional control at the time. We find that the results are unchanged.
} 


\subsection{Labour productivity and job reallocation}

In table 4 we explore the effect of EPL on labour productivity finding strong and significantly negative coefficients of around -0.27 (which can be quantified with the previous exercise in an increase of 8.6 percent in the average value added per worker ratio in high versus low reallocation industries.

Regarding job reallocation, although the negative effect of EPL on job flows is well established (see references in section 2), most previous studies look at sectoral rather than firm level data. Our results are presented in Table 5. The coefficients estimated in columns 1 and 2 are similar in magnitude (-0.052 and -0.044). In summary we find that the sign of the coefficient on the interaction terms is negative and statistically significant i.e. firms in more volatile industries present lower levels of job reallocation in countries with more stringent employment protection laws. These results are in line with most of the previous literature on EPL and job flows.

In order to get an idea of the magnitude of the effects, we consider the differential in the (average) reallocation rate between the two industries at the $10^{\text {th }}$ and $90^{\text {th }}$ percentile of the computed distribution of "frictionless" reallocation. Then our estimates imply that reducing employment protection from the level of Greece in 1997 to that in Ireland the same year (this shift correspond to the $90^{\text {th }}$ to the $10^{\text {th }}$ percentile of the country-by-year EPL distribution in our sample) increases yearly reallocation by 1,4 percentage points, against a median reallocation rate of firms in our sample of $5.7 \%$.

The negative results on labour productivity are consistent with previous empirical literature (e.g. Autor et al, 2007 and Bassanini et al., 2009) and are somewhat expected as we have assessed that EPL not only reduces job flows in table 5 (as in much of the previous literature) but also reduces capital investment per unit of labour (table 3 ) and the capital-labour ratio (table 2). If reallocation of labour is important and EPL hampers job reallocation across and within sectors, then productivity falls. Indeed, finding an effect of EPL on job reallocation is a pre-requisite to claim that dismissal restrictions hamper the optimization of resources and allocative efficiency (Bertola, 1990). On top of that, labour productivity also falls because capital investment per worker falls. 


\section{EPL and the role of Financial Market Imperfections}

We are now in the position to analyse the results on the joint effect of EPL and financial constraints on the outcome variables i.e. the differential effect of EPL on all outcome variables for financially constrained firms. Our empirical strategy, outlined in equation (3), amounts to evaluate whether there is a differential effect of EPL in firms with different levels of internal resources on the variables analysed so far: capital per worker, investment per worker, value added per worker and job reallocation rates. We build two different measures of financial liquidity, one based on the flow of internal resources potentially available for investment purposes (operating cash-flow) and, for robustness purposes, one based on the stock of internal resources (net liquid assets, see robustness section for details).

As the financial variables that measure liquidity vary at the firm level, we are now able to control for any time-invariant unobserved firm characteristic that may affect the dependent variables while being correlated with the level of firms' internal resources by the use of firms fixed effects, thus fully exploiting the firm-level dimension of the dataset.

As before, we first look at the effect on capital and investment normalized by unit of labour and on the capital-labour ratio (section 6.1). Then we look at the effects on labour productivity and job reallocation (section 6.2).

\subsection{Capital and investment per worker}

Table 6 reports results on the ratio of capital to labour. The first column simply expands the specification reported in the second column of table 2 by adding firm cash-flow (and its interactions with respectively EPL, benchflows and EPLXbenchflows) and the lagged value of ROA to control for the profitability of the firm. This column shows that the mere presence of firm-level measures of liquidity (and their interaction terms) in the estimating equation does not alter the result that EPL has a negative significant impact on $K / L$ in high reallocation sectors relative to low reallocation sectors, as shown by the negative and significant coefficient of EPL $\times$ BF. $^{8}$

To assess whether firms with higher levels of internal resources respond differently to EPL, we need to look at the coefficient of the triple interaction term EPL $\times$ BF $\times$ Internal Resources. The coefficient is negative and significant, meaning that the negative effect of EPL on the capital-

\footnotetext{
${ }^{8}$ Note, however, that this effect is evaluated at zero-cash flow, but simulations at values at the $90^{\text {th }}$ and $10^{\text {th }}$ percentile of the cash-flow distribution show that the effect is always negative and statistically significant.
} 
labour ratio is larger the higher the level of internal resources of the firm. This counterintuitive results is likely driven by composition effects at the industry level, as firms producing larger cash-flow not only have higher collateral and easier access to credit, but are also different along other dimensions, such as growth prospects and exporting propensity.

For this reason the second column includes firms fixed effects and therefore controls for all firms' time-invariant unobserved characteristics that may be correlated with cash-flow, thus identifying the effects of interest from contrasts of within-firm changes. We now find that EPL still reduces the capital-labour ratio, but less so in firms with higher internal resources as the coefficient on $\mathrm{EPL} \times \mathrm{BF} \times$ Internal Resources is now positive and significant. Having a high cash flow thus reduces significantly the negative effect on the capital-labour ratio or equivalently, from the point of view of financially constrained firms, they have to reduce capital more when EPL increases and they are "held up" by the request of higher wages. This result is robust to the inclusion of country by year dummies (column 3); the use of a different measure of liquidity (column 4, further discussed in the robustness section); additional firm-level controls (column 5) and the use of UK job turnover as an alternative proxy for the frictionless job reallocation rate (column 6).

We have interpreted the negative effect of EPL on capital investment and the capital-labour ratio in the basic specification of equation (1) along the lines of the "hold up" theory. The results of equation (3), which looks at differential effects depending on the internal financial structure of firms, are consistent with the same view: the presence of stricter EPL disincentives the use of internal funds for financing new investments: i.e., if capital is largely sunk and high EPL favours ex-post profit appropriation by workers, firms will use their internal funds to pay higher wages and will invest less. This is all the more true for financially constrained firms with low liquidity. Table 7 turns to the results on investment per worker. It shows in all columns that having a high cash-flow does not make any difference for the negative impact on investment per unit of labour as coefficient on EPL $\times \mathrm{BF} \times$ Internal Resources is always insignificant, except for column 4 which uses net liquid assets and shows that in the face of high EPL more liquid firms tend to invest more.

We speculate that the absence of a differential effect on the investment level of firms with different levels of liquidity may be due to the lumpy nature of the investment process, as investments episodes tend to be rare and of substantial magnitude. Indeed in our data, more than 
$6 \%$ of observations on investments are zero and the observed distribution is extremely skewed to the left.

\subsection{Labour productivity and job reallocation}

Table 8 considers labour productivity. Overall, the results indicate that the negative impact of EPL does not seem to depend of the level firms' internal resources as the coefficient on EPL $\times$ $\mathrm{BF} \times$ Internal Resources is always insignificant, except for column 6 which uses UK job reallocation.

Finally, we do not find any differential effect of EPL on job reallocation depending on the level of internal resources either (table 9 except for column 4 which uses net liquid assets).

Summing up, the result on capital per worker seems to favour the interpretation that financial constraints exacerbate the negative effects of EPL on capital deepening. However, we take this finding as suggestive but only tentative as, when we turn to investments, we find no (or at best only weak) evidence of a differential effect of EPL on firms with different levels of liquid resources, a result possibly due to the lumpiness of the investment process which deserves further exploration. Finally, neither value added per worker nor job reallocation are affected differentially by EPL in firms with different levels of internal resources.

\section{Robustness checks}

In this section, we provide a number of robustness checks for our baseline regressions. We test robustness with respect to $a$ ) benchmark measure of job reallocation; $b$ ) balanced-unbalanced samples; $c$ ) the specification of the equation; $d$ ) exclusions of specific sectors or countries; $e$ ) the measure of EPL; $f$ ) the firm-level measure of internal resources.

a) The last column of tables 2 to 9 uses UK turnover as benchmark to test the robustness of our benchmark measure. The results show that in all cases the results are negative and larger than with the Ciccone-Papaioannou measure except for the case of table 5 (job reallocation) where "EPL $\times$ FJR" is now insignificant and for the case of table $8(\mathrm{VA} / \mathrm{L})$ where the coefficient of interest "EPL $\times$ FJR $\times$ Internal Resources" becomes significant. The difference between the UK reallocation benchmark and the world-average measure reflect the idiosyncrasies of the UK labour market as explained in the data section. 
b) The sample is unbalanced, therefore includes entry of new firms and exit. Thus, the overall effect we measure includes both the direct impact on incumbent firms and the indirect compositional effect through entry and exit. However, we are not able to disentangle the two effects primarily because firms can enter or exit the Amadeus sample for many reasons (e.g. merger, acquisition, change of name, change in the obligation to provide/have a balance sheet) that prevent us from reliably measuring the true entry and exit. To try and have an idea of the extent to which our effects are due to the churning of firms, we compare the results obtained on the unbalanced sample (which includes entry and exit) with results on a balanced sample of firms that stay in sample every year from 1997 to 2003 . We have a bit less than 500.000 of such firms in the sample. We find that the results on the balanced sample are virtually the same as on the unbalanced sample. If anything, they are quantitatively stronger.

c) We also run regressions where the dependent variable is in growth rates rather than levels, to allow for the possibility that EPL might affect the growth rate of variables rather than levels. However, notice that investment per worker $(I / L)$ and Job Reallocation are already growth rates ( $I / L$ is precisely the rate of change of $K / L$ ). Therefore we regressed the rate of change of $V A / L$ on EPL (including the interaction terms with firms internal resources) and found no differential effect of EPL in firms with larger levels of internal resources, very much as in the case of the variable in levels. Additionally, one may also worry that our variables may be affected by past EPL. However, these effects are likely to be captured by the current level of EPL given the wellknown limited time variability of EPL, and by country and time dummies.

d) We assess the impact of the exclusion of specific sectors in the regression. We have used our preferred specification, which includes sector by year and country by year fixed effects (and corresponds to columns 2 in tables 2 to 5). Hence, identification relies in within country variation across sectors, in the spirit of the original contribution of Rajan and Zingales (1998). Dropping one sector at a time never turns the sign of our variable of interest, the interaction of EPL with benchmark flows, which remains negative when $J R, I / L, K / L$ and $V A / L$ are the dependent variables in each of the 446 regressions. Moreover, the coefficients are always statistically significant at the $10 \%$ level, the $t$-statistics ranging from 3.2 to 5.69 in the case of JR, from 1.65 to 3 in the case of $\mathrm{I} / \mathrm{L}$, from 2.37 to 3.52 in $K / L$ regressions and from 1.89 to 3.16 (except one single case where the $t$-statistic is 1.38 ) when the dependent variable is $V A / L$. 

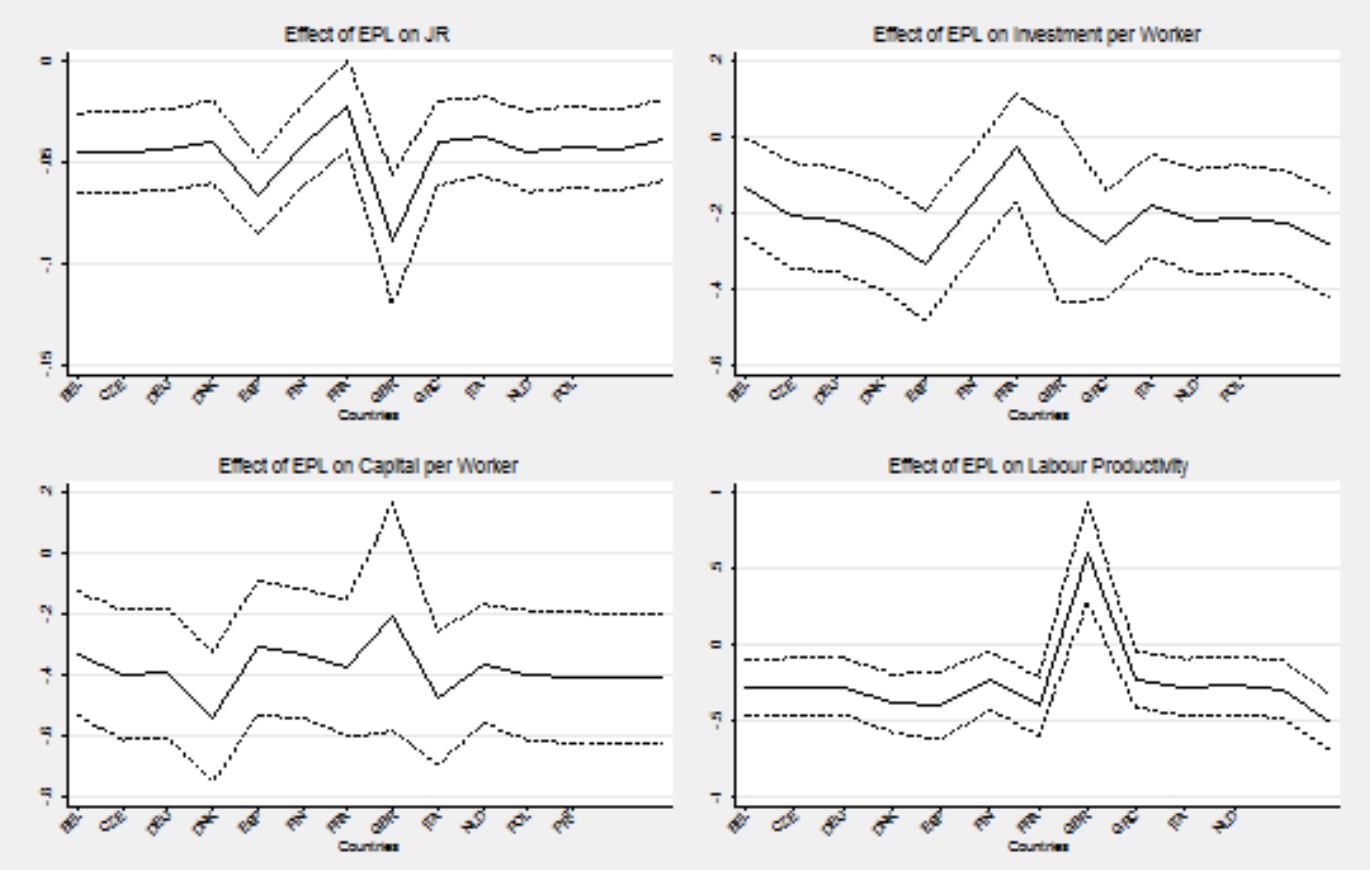

Note: Dashed lines present $90 \%$ confidence intervals

Figure 3. Effect of EPL on $K / L, I / L, V A / L$ and $J R$ excluding one country at the time

Our next exercise examines the impact of the presence of specific countries in the sample. Figure 3 shows the impact of dropping one country at a time in each of our outcome variables, focusing on the specification that includes country by year and sector by year fixed effects. The estimates presented in the text are relatively stable when specific countries are excluded from the sample. In all the cases the estimated effects retain their negative sign, with one notable exception; the interaction term $E P L \times$ BenchFlows in the labour productivity regression becomes positive when the UK is excluded from the sample. The exclusion of France from $J R$ regressions (and of France and UK for $I / L$ regressions) also somewhat dampens the negative sign, as the coefficient of the interaction term, although retaining its negative sign, becomes non-significant at standards levels of testing.

e) EPL data is available up to 2003, while our firm level dataset contains information for 2004 and 2005. We have investigated a possible extension of the OECD EPL index. The Fondazione Rodolfo de Benedetti has collected information on EPL reforms in the period 1986-2005 and classifies them in structural and marginal, depending on the scope of the regulatory change. None of the countries in our sample experienced structural EPL reforms during 2004-2005, but some did follow marginal reforms. We have repeated our regressions under the assumption that the EPL levels remain constant in each country after 2003, and results (available upon request) are 
qualitatively similar to those presented here. Extending the sample backwards up to 1994 (where we have fewer firms), does not seem to alter either the nature of our estimates.

Finally, we look at differential effects of employment protection for temporary and permanent workers. For this purpose, we introduce in turn the sub-indices that the OECD (2004) provides for these two contractual figures. As in the case with the overall strictness of EPL index, these indices range from 0 to 6 according to the increasing strictness of regulations. The results suggest a stronger effect of regulation for regular contracts than for temporaries. The effect of both indices is negative in the investment and labour productivity regressions, but the magnitude of EPL for temporary contracts is almost 10 times smaller than for regular contracts (and non-statistically different from zero in the case of I/L). Similarly, the negative impact of EPL for regular contracts on the capital-labour ratio almost doubles the effect of temporary contracts. In both cases the coefficients are significant at standard levels of testing.

f) We also test the robustness of our results with respect to the variable that proxies for firm liquidity. Following Cleary, Povel and Raith (2005), we use an alternative measure of internal resources, called net liquid assets. This is a stock measure of internal funds defined as current assets minus current liabilities which equals net working capital. The reason for adopting this stock measure is that measuring internal funds by using a flow variable, such as cash-flow, correctly accounts for current changes in internal funds but ignores existing funds carried over from the last period. Of course, measuring internal funds with a stock variable as (lagged) liquid assets, on the other hand, ignores all recent cash flow that is immediately invested and therefore never shows up in the end-of-period stock variable. For this reason, we use both variables. We include a specification in column 4 of each table from 6 to 9 that largely confirms the results obtained using cash-flow.

\section{Conclusion and policy implications}

This paper is a first attempt to assess the joint impact of government mandate employment protection and financial market imperfections exploiting comparable micro-data in a cross-country context.

We proceed in two steps. We first analyse the average effect of EPL on capital per worker, investment per worker and labour productivity. We find that EPL reduces all of them in high reallocation sectors relative to low reallocation sectors. The magnitude of the effect is economically not negligible and lies around $12 \%, 6.8 \%$ and $8.6 \%$ of the difference in, respectively, the capital- 
labour ratio, investment per worker and labour productivity of high vs. low reallocation industries.

These findings bring about potentially important policy implications. They suggest that the debate on the role of EPL needs to consider not only the direct effect on employment flows, but also the indirect impact due to distorted incentives on capital accumulation and investment.

The first implication of these results is that investment subsidies, which usually do not take into account the possible distortions induced by EPL, may be insufficient. The second implication is that the distorted incentives for investment and their productivity effects (a substantial $8.6 \%$ of the difference between value added per worker in high vs. low reallocation industries) may slow down the structural change from manufacturing industries (low reallocation sectors) towards services (high reallocation sectors) as in Rogerson (2008).

Our results also allow us entering into the debate on partial (in the sense of deregulating temporary contracts) versus comprehensive EPL reform. In many countries the reform of EPL has been partial. Overall the literature indicates important potential pitfalls related to partial reforms, and most authors seem to favour a reduction in EPL for permanent contracts. However, our results (the results with the EPL index for temporary contracts are much weaker) indicate that the partial EPL reform could help attenuating some of the disincentive effects on investment highlighted here, because temporary workers have lower bargaining power than permanent workers and reduce the incidence of the "hold up" problem. Temporary contracts have themselves ambiguous effects on productivity, depending on whether they act mainly as a 'stepping stone' or 'dead end jobs'.

Regarding the role of credit market imperfections in shaping firms' response to strict employment protection, our results suggest that sectors and countries where access to credit is difficult are expected to have a lower capital stock per worker. At his stage, we take this finding as suggestive but only tentative as we find only weak (if any) evidence of a differential effect of EPL on investments in firms with different levels of liquid resources.

This last finding is potentially quite important because, if correct, it provides confirmation that exogenous improvements in credit markets may alleviate the negative impact of labour market restrictions on capital deepening and technology adoption.

Some recent papers, e.g. Fella (2006) and Pissarides $(2001,2004)$ highlight the productive role of EPL as (additional) insurance against income risk. The presence of unemployment insurance re- 
duces the insurance gains from EPL but also more developed capital markets may have made it less costly for workers to deal with the unemployment risk by saving and borrowing on the capital market, again reducing the gains from insurance via EPL. Thus more liquid financial markets reduce the importance of EPL for workers. From the point of view of firms we find that firms with financial constraints reduce their capital stock per worker more, thus more liquid financial markets alleviate the hold-up problem.

Hence, at the country level, and as far as efficiency is concerned, financially underdeveloped countries are the ones who would benefit the most from reductions in EPL. However, from the point of view of overall welfare, employment protection policies should be jointly evaluated with financial market frictions in the classic efficiency-equality trade-off: on the one hand, the negative effects of firing restrictions on firms' efficiency are amplified in countries with severe financial market imperfections; on the other hand, workers benefit more from EPL precisely in those countries where financial markets are more underdeveloped. The reason is that EPL provides insurance from labour market risk, which is more valuable in countries where other insurance mechanisms are absent (Bertola, 2004). By the same token countries with more liquid financial markets would benefit less in terms of productivity growth from the reduction of EPL, but it is also true that in these same countries the insurance role of firing restrictions is less important precisely because of the presence of more liquid financial markets. 


\section{DATA APPENDIX}

This appendix describes the construction of the main variables used in the analysis. The unit of observation in Amadeus is the firm. We extract from the database the following variables from the balance sheet and profit and loss accounts: total assets, fixed assets, fixed tangible assets, value added, profit before taxes, cash-flow, net liquid assets, exports and depreciation. We add to this initial set the main sector of operation of the firm, the number of employees and the number of subsidiaries.

All nominal series used in the analysis are deflated using 2-digit sectoral level (60 sectors) deflators of value added (benchmark year is 1995), and converted into Euros using sectoral PPP exchange rates at the same level of aggregation. The base country for PPPs is Germany. The deflator and PPP exchange rates are obtained from EUKLEMS.

Investment in the paper is defined as the difference between book value of fixed assets in year $t+1$ and fixed assets in year $t$ plus depreciation in year $t+1$. Using the series of investment properly deflated, we construct a new series of capital following the perpetual inventory method. For these purposes, we rely on the harmonized depreciation rates by industry obtained from EUKELMS.

Value added and capital per worker (computed using the perpetual inventory method) are defined as the logarithm of the respective ratios, while investment per worker is the logarithm of 1 plus the ratio of investment and employment. This avoids dropping the zeros in this variable. ${ }^{9}$ Return on assets is defined as profit before taxes divided by total assets, while cash flows and net liquid assets are normalized by tangible assets in the previous accounting period. Job reallocation at the firm level is defined in parallel with the sectoral definition of Davis and Haltiwanger (1990). It is the absolute value of the change in employment between two consecutive periods divided by the average employment between both periods. Hence, it is a measure that treats symmetrically the creation and destruction of jobs and is bounded between 0 and 2 .

We trimmed outlier observations in several steps. We first drop $1 \%$ of each country sample constituted by the extreme values of both tails in the distribution of the key original variables (fixed assets, tangible assets, cash flow, profits, employment and value added). After constructing the ratios that will be used in the analysis, we further exclude observations whose difference with respect to the median (in absolute value) exceeds five times the absolute distance between the $75^{\text {th }}$ and $25^{\text {th }}$ percentile in the distribution.

\footnotetext{
${ }^{9}$ We have experimented with the raw values of the ratio, and dropping the zeros before taking the logarithmic transformation and results are not affected by this transformation.
} 
The resulting panel is highly unbalanced. In order to preserve the comparability across exercises using different dependent variables, we restrict the analysis presented in the paper to a reduced sample where we drop observations with missing fixed assets, employment or the ratio of cash flow over fixed assets in period $t$ - 1 . The cash flow condition results in losing about one third of the sample.

We use the OECD measure of employment protection regulation (OECD, 2004). EPL refers to the institutions related to the dissolution of matches between firms and workers. Most notably, administrative and legal procedures including notice periods, severance pay and firing taxes. These arrangements may be the result of government legislation, collective labour agreements and/or individual contracts.

The overall EPL indicator is a weighted average of 18 basic items. The items are grouped into EPL for: $i$ ) employment protection of regular workers against individual dismissal, $i i$ ) specific requirements for collective dismissals, and iii) regulation of temporary forms of employment. Within the EPL items for regular workers against individual dismissal we can again distinguish three subgroups: $i$ ) procedural inconveniences that the employer may face when starting the dismissal process, $\mathrm{ii}$ ) legislative provisions that state under which conditions a dismissal is justified or fair, and iii) regulations on notice periods and severance pay. For each item the score is normalised on a scale from 0 to 6 , where a higher score represents more strict regulation on the relevant item. ${ }^{10}$

\footnotetext{
${ }^{10}$ The OECD indicator has some well-known limitations. In particular, the weights of the various components are subjective and are attributed on the basis of legislative provisions, while in practice legislative provisions can be extended by contractual provisions, which are typically not incorporated in the indicator. Also, the interpretation of the regulations by the court generates variation in EPL strictness over time and across countries that is not captured by the indices, e.g. court decisions may be affected by underlying labour market performance (Ichino et al., 2003).
} 


\begin{tabular}{|c|c|c|c|c|c|c|}
\hline & Country & $J R$ & $I / L$ & $K / L$ & $V A / L$ & $E P L$ \\
\hline Mean & BEL & 0.152 & 9.5 & 64.418 & 58.961 & 2.2 \\
\hline St. Dev & & $(0.233)$ & (12.539) & $(83.392)$ & (28.683) & (0) \\
\hline Min & & 0 & 0 & 1 & 1.487 & 2.2 \\
\hline Max & & 1.974 & 102.593 & 12263.46 & 522.272 & 2.2 \\
\hline $\mathrm{N}$ & & 349027 & 339519 & 364724 & 34642 & 387902 \\
\hline Mean & CZE & 0.054 & 3.832 & 19.766 & 14.532 & 1.9 \\
\hline St. Dev & & $(0.187)$ & (4.953) & $(23.325)$ & (11.233) & $(0)$ \\
\hline Min & & 0 & 0 & 1.001 & 1.012 & 1.9 \\
\hline Max & & 1.941 & 84.625 & 414.271 & 188.697 & 1.9 \\
\hline $\mathrm{N}$ & & 14876 & 12260 & 14509 & 6681 & 16000 \\
\hline Mean & DEU & 0.078 & 10.933 & 70.181 & 64.665 & 2.444 \\
\hline St. Dev & & $(0.132)$ & $(13.652)$ & (110.186) & (33.209) & $(0.073)$ \\
\hline Min & & 0 & 0 & 1.123 & 5.414 & 2.35 \\
\hline Max & & 1.589 & 117.46 & 1436.537 & 370.062 & 2.5 \\
\hline $\mathrm{N}$ & & 2512 & 1878 & 2435 & 2442 & 2758 \\
\hline Mean & DNK & 0.124 & 4.849 & 24.923 & 56.152 & 1.4 \\
\hline St. Dev & & $(0.189)$ & $(6.571)$ & $(28.232)$ & (32.499) & (0) \\
\hline Min & & 0 & 0 & 1 & 2.226 & 1.4 \\
\hline Max & & 1.978 & 52.062 & 561.5 & 380.262 & 1.4 \\
\hline $\mathrm{N}$ & & 65293 & 52730 & 65481 & 30971 & 70197 \\
\hline Mean & ESP & 0.172 & 5.462 & 23.294 & 30.684 & 3.02 \\
\hline St. Dev & & $(0.242)$ & (7.576) & (31.134) & (16.85) & $(0.098)$ \\
\hline Min & & 0 & 0 & 1 & 1 & 2.9 \\
\hline Max & & 1.98 & 60.015 & 6247.4 & 187.828 & 3.1 \\
\hline $\mathrm{N}$ & & 609169 & 527234 & 626615 & 649027 & 687901 \\
\hline Mean & FIN & 0.117 & 5.344 & 19.328 & 39.677 & 2.04 \\
\hline St. Dev & & (0.199) & (7.509) & (25.299) & (21.348) & $(0.049)$ \\
\hline Min & & 0 & 0 & 1 & 1.006 & 2 \\
\hline Max & & 1.86 & 61.178 & 1938.718 & 734.945 & 2.1 \\
\hline $\mathrm{N}$ & & 65471 & 51378 & 64185 & 60227 & 71210 \\
\hline Mean & FRA & 0.119 & 2.424 & 13.229 & 37.045 & 3 \\
\hline St. Dev & & $(0.177)$ & (3.104) & (78.598) & (22.699) & (0) \\
\hline Min & & 0 & 0 & 1 & 1.057 & 3 \\
\hline Max & & 1.968 & 22.78 & 37662.27 & 3751.063 & 3 \\
\hline $\mathrm{N}$ & & 624689 & 558202 & 617973 & 520317 & 688799 \\
\hline Mean & GBR & 0.121 & 3.792 & 21.803 & 32.473 & 0.655 \\
\hline St. Dev & & $(0.17)$ & $(4.773)$ & $(22.886)$ & $(22.241)$ & $(0.045)$ \\
\hline Min & & 0 & 0 & 1 & 1.009 & 0.6 \\
\hline Max & & 1.984 & 50.516 & 772.072 & 449.539 & 0.7 \\
\hline $\mathrm{N}$ & & 208488 & 173950 & 205436 & 161299 & 230928 \\
\hline
\end{tabular}

Note: Capital, investment and value added are expressed in thousands of 1995 German Euros. 


\section{Table A1: Descriptive statistics by country (continued)}

\begin{tabular}{|c|c|c|c|c|c|c|}
\hline Mean & GRC & 0.051 & 7.663 & 32.43 & - & 3.381 \\
\hline St. Dev & & $(0.16)$ & (11.562) & (37.036) & - & $(0.263)$ \\
\hline Min & & 0 & 0 & 1 & - & 2.8 \\
\hline Max & & 1.939 & 142.821 & 996.7 & - & 3.5 \\
\hline $\mathrm{N}$ & & 45811 & 44813 & 47598 & 0 & 50709 \\
\hline Mean & ITA & 0.189 & 9.929 & 41.161 & 47.285 & 2.416 \\
\hline St. Dev & & $(0.235)$ & (12.587) & $(52.424)$ & $(23.867)$ & $(0.406)$ \\
\hline Min & & 0 & 0 & 1.001 & 1.033 & 1.9 \\
\hline Max & & 1.98 & 118.55 & 9075.759 & 412.342 & 3.26 \\
\hline $\mathrm{N}$ & & 335561 & 299496 & 336108 & 346551 & 375985 \\
\hline Mean & NLD & 0.118 & 6.833 & 32.504 & 61.187 & 2.152 \\
\hline St. Dev & & $(0.181)$ & (8.591) & (39.97) & (37.606) & $(0.168)$ \\
\hline Min & & 0 & 0 & 1.033 & 3.389 & 2.1 \\
\hline Max & & 1.969 & 71.258 & 444.661 & 398.823 & 2.7 \\
\hline $\mathrm{N}$ & & 8127 & 5766 & 7839 & 6687 & 8644 \\
\hline Mean & POL & 0.345 & 10.086 & 29.96 & 25.429 & 1.48 \\
\hline St. Dev & & $(0.553)$ & $(25.013)$ & (79.881) & (51.419) & $(0.162)$ \\
\hline Min & & 0 & 0 & 1 & 1.009 & 1.24 \\
\hline Max & & 1.966 & 715.802 & 2348.037 & 960.591 & 1.7 \\
\hline $\mathrm{N}$ & & 15024 & 13356 & 15393 & 11802 & 16832 \\
\hline Mean & PRT & 0.11 & 9.472 & 31.223 & 29.946 & 3.7 \\
\hline St. Dev & & $(0.164)$ & (11.668) & (27.912) & (17.746) & $(0)$ \\
\hline Min & & 0 & 0 & 1.043 & 1.907 & 3.7 \\
\hline Max & & 1.636 & 99.328 & 363.005 & 208.223 & 3.7 \\
\hline $\mathrm{N}$ & & 3378 & 1985 & 3268 & 3357 & 3559 \\
\hline Mean & SWE & 0.104 & 3.133 & 18.335 & 26.249 & 2.2 \\
\hline St. Dev & & $(0.201)$ & (4.583) & (258.488) & (27.557) & (0) \\
\hline Min & & 0 & 0 & 1 & 1 & 2.2 \\
\hline Max & & 1.981 & 67.85 & 78835.06 & 1920.626 & 2.2 \\
\hline $\mathrm{N}$ & & 339891 & 320127 & 343621 & 327447 & 386296 \\
\hline Mean & Total & 0.142 & 5.506 & 28.201 & 35.46 & 2.474 \\
\hline St. Dev & & $(0.218)$ & $(8.835)$ & (108.568) & (24.049) & $(0.697)$ \\
\hline Min & & 0 & 0 & 1 & 1 & 0.6 \\
\hline Max & & 1.984 & 715.802 & 78835.06 & 3751.063 & 3.7 \\
\hline $\mathrm{N}$ & & 2687317 & 2402694 & 2715185 & 2161450 & 2997720 \\
\hline
\end{tabular}

Note: Capital, investment and value added are expressed in thousands of 1995 German Euros. 
Table A2: Descriptive statistics by year

\begin{tabular}{|c|c|c|c|c|c|c|}
\hline & Year & $J R$ & $I / L$ & $K / L$ & $V A / L$ & $E P L$ \\
\hline Mean & 1997 & 0.143 & 6.538 & 26.769 & 38.079 & 2.563 \\
\hline St. Dev & & $(0.209)$ & (9.615) & (36.109) & $(22.058)$ & (0.819) \\
\hline Min & & 0 & 0 & 1 & 1 & 0.6 \\
\hline Max & & 1.959 & 117.46 & 1436.537 & 300.506 & 3.7 \\
\hline $\mathrm{N}$ & & 214629 & 195799 & 229329 & 165680 & 237506 \\
\hline Mean & 1998 & 0.147 & 6.415 & 26.869 & 36.052 & 2.479 \\
\hline St. Dev & & $(0.215)$ & $(9.503)$ & (35.517) & $(21.991)$ & (0.719) \\
\hline Min & & 0 & 0 & 1 & 1 & 0.6 \\
\hline Max & & 1.969 & 101.085 & 1238.155 & 324.471 & 3.7 \\
\hline $\mathrm{N}$ & & 262352 & 240803 & 278686 & 206439 & 290602 \\
\hline Mean & 1999 & 0.147 & 6.414 & 26.518 & 36.302 & 2.475 \\
\hline St. Dev & & $(0.231)$ & (11.126) & (38.698) & $(23.861)$ & $(0.67)$ \\
\hline Min & & 0 & 0 & 1 & 1.005 & 0.6 \\
\hline Max & & 1.98 & 715.802 & 2348.037 & 960.591 & 3.7 \\
\hline $\mathrm{N}$ & & 348287 & 322696 & 369759 & 279540 & 389642 \\
\hline Mean & 2000 & 0.15 & 5.558 & 27.148 & 36.086 & 2.481 \\
\hline St. Dev & & $(0.233)$ & (8.729) & (38.224) & (21.782) & $(0.64)$ \\
\hline Min & & 0 & 0 & 1 & 1.013 & 0.68 \\
\hline Max & & 1.98 & 98.253 & 3000.106 & 604.335 & 3.7 \\
\hline $\mathrm{N}$ & & 395333 & 364093 & 421273 & 324152 & 447728 \\
\hline Mean & 2001 & 0.15 & 5.043 & 27.52 & 35.438 & 2.442 \\
\hline St. Dev & & $(0.222)$ & (7.991) & $(40.927)$ & $(22.843)$ & $(0.701)$ \\
\hline Min & & 0 & 0 & 1 & 1.003 & 0.68 \\
\hline Max & & 1.981 & 102.302 & 4287.555 & 1386.365 & 3.7 \\
\hline $\mathrm{N}$ & & 455098 & 417483 & 473935 & 368305 & 510595 \\
\hline Mean & 2002 & 0.136 & 4.796 & 28.302 & 34.365 & 2.474 \\
\hline St. Dev & & $(0.211)$ & (7.554) & (62.994) & $(24.576)$ & $(0.694)$ \\
\hline Min & & 0 & 0 & 1 & 1.002 & 0.7 \\
\hline Max & & 1.984 & 85.243 & 17624.67 & 1913.918 & 3.7 \\
\hline $\mathrm{N}$ & & 512722 & 463466 & 520229 & 422183 & 578153 \\
\hline Mean & 2003 & 0.129 & 4.975 & 33.028 & 34.134 & 2.453 \\
\hline St. Dev & & $(0.203)$ & $(8.048)$ & (254.416) & $(27.865)$ & $(0.687)$ \\
\hline Min & & 0 & 0 & 1 & 1.006 & 0.7 \\
\hline Max & & 1.975 & 142.821 & 78835.06 & 3751.063 & 3.7 \\
\hline $\mathrm{N}$ & & 498896 & 398354 & 421974 & 395151 & 543494 \\
\hline
\end{tabular}

Note: Capital, investment and value added are expressed in thousands of 1995 German Euros. 


\section{Bibliography}

Alesina, A., S. Ardagna, G. Nicoletti, F. Schiantarelli, (2005), Regulation and Investment, Journal of the European Economic Association, 3(4), 791-825.

Alesina, A. and Joseph Zeira, (2006), Technology and Labour Regulations, Harvard Institute of Economic Research DP 2123.

Atanassov J. and E.H. Kim, (2008) Labour and Corporate Governance: International Evidence from Restructuring Decisions, Journal of Finance, forthcoming

Autor, David H., William R. Kerr and Adriana D. Kugler, (2007), Do Employment Protections Reduce Productivity? Evidence from U.S. States, The Economic Journal, 117 June, 189271.

Bassanini A., Luca Nunziata and D. Venn, (2009) Job protection legislation and productivity growth in OECD countries, Economic Policy, forthcoming.

Belot, M. and J.C. van Ours, 2004, Does the recent success of some OECD countries in lowering their unemployment rates lie in the clever design of their labour market reforms?, Oxford Economic Papers, vol. 56, no. 4, pp. 621-642.

Bentolila, S. and J. Dolado, 1994, Labour Flexibility and Wages: Lessons from Spain, Economic Policy, vol. 18, pp. 53-100.

Bertola, Giuseppe, (1990), Job Security, Employment, and Wages, European Economic Review, 54(4), 851-79.

Bertola, G. (1994), 'Flexibility, Investment, and Growth', Journal of Monetary Economics, $34(2), 215-238$.

Bertola, Giuseppe, (2004), A Pure Theory of Job Security and Labour Income Risk, Review of Economic Studies 71(1), 43-61

Blanchard, O. and J. Tirole, 2004, The Optimal Design of Unemployment Insurance and Employment Protection. A First Pass, NBER Working Paper 10443, NBER, Cambridge.

Boot, L.; V. Aivazian; A. Demirgüç-Kmit; and V. Maksimovic, (2001) Capital Structures in Developing Countries, Journal of Finance, 56, 87-130.

Bozcaya Ant and William R. Kerr, (2008) Labour Regulations and European Industrial Specialization: Evidence from Private Equity Investments, mimeograph, Harvard University

Caballero, R. and M.L. Hammour, 1998, The Macroeconomics of Specificity, Journal of Political Economy, vol. 106, no. 4, pp. 24-767.

Calcagnini G. and G. Giombini, (2008), Does Employment Protection Legislation affect Firm Investment? The European Case, mimeograph.

Ciccone A. and E. Papaioannou (2006), Adjustment to Target Capital, Finance, and Growth, mimeograph, UPF.

Ciccone A. and E. Papaioannou (2007), Red Tape and Delayed Entry, The Journal of European Economic Association, Papers and Proceedings, 2007, 444-458.

Cingano F, M. Leonardi, J. Messina and G. Pica (2008), Employment Protection Legislation, Productivity and Investment: Evidence from Italy, mimeograph, University of Salerno 
Cleary, Sean, Paul Povel and Michael Raith, (2005), The U-shaped Investment Curve: Theory and Evidence, Journal of Financial and Quantitative Analysis, 42, 1-39.

Fazzari, Steven, R. Glenn Hubbard and Bruce Petersen (1988): Financing Constraints and Corporate Investment. Brookings Papers on Economic Activity, 141-195.

Fella, G., (2006), Optimal Severance Pay in a Matching Model, mimeo, Queen Mary, University of London, London.

Fonseca Raquel and Natalia Utrero-González, (2005), Financial Development, Labour and Market Regulations and Growth, EPEE Working Paper 05-05

Garibaldi and Violante, 2005, The Employment Effects of Severance Payments with Wage Rigidities, The Economic Journal, Vol. 115, pp. 799-832.

Giannangeli, Silvia and Gómez-Salvador, Ramón. (2008) Evolution and Sources of Manufacturing Productivity Growth: Evidence from a Panel of European Countries. ECB Working Paper No. 914.

Gómez-Salvador, Ramón, Julián Messina and Giovanna Vallanti, (2004), Gross job flows and institutions in Europe, Labour Economics, August 2004, 11(4): 469-485.

Haltiwanger J.. S. Scarpetta and H. Schweiger, (2006), Assessing Job Flows across Countries: The Role of Industry, Firm Size and Regulations, IZA Discussion Papers 2450, Institute for the Study of Labour

Hopenhayn, H. and R. Rogerson, 1993, Job Turnover and Policy Evaluation: A General Equilibrium Analysis, The Journal of Political Economy, vol. 101, no. 5, pp. 915-938.

Ichino, A., M. Polo and E. Rettore, (2003), Are judges biased by labour market conditions?, European Economic Review, 47(5) pp 913-944.

Ichino, A. and R.T. Riphahn, (2005), The Effect of Employment Protection on Worker Effort: A Comparison of Absenteeism During and After Probation, Journal of the European Economic Association, 3(1), 120-143

Kaplan, Steven and Luigi Zingales, (1997), Do Investment-Cash Flow Sensitivities Provide Useful Measures of Financing Constraints?, Quarterly Journal of Economics, 112, 169215.

Kent C. and J. Simon, (2007), Productivity Growth: The Effect of Market Regulations, RBA Research Discussion Papers rdp2007-04, Reserve Bank of Australia

Koeniger, Winfried and Marco Leonardi, (2007), "Capital Deepening and Wage Differentials: Germany versus US". Economic Policy, Vol. 22, No. 49, pp. 71-116,

Konings, Jozef, Patrick Van Cayseele and Frederic Warzynski (2005), The Effects of Privatization and Competitive Pressure on Firms' Price-Cost Margins: Micro Evidence from Emerging Economies, The Review of Economics and Statistics, 87(1): 124-134

Kugler, A., and Giovanni Pica, (2008), Effects of Employment Protection on Worker and Job Flows: Evidence from the 1990 Italian Reform, Labour Economics, Volume 15, Issue 1, pp. 78-95.

Lagos, R. (2006), A Model of TFP, Review of Economic Studies, vol. 73, no. 4, pp. 983-1007.

Leonardi, M., and Giovanni Pica, (2008), Employment Protection Legislation and Wages, IZA DP 2680. 
Messina, Julián and Giovanna Vallanti (2007). Job Flow Dynamics and Firing Restrictions: the European Evidence". The Economic Journal, 117:279-301.

Micco Alejandro and Carmen Pagés, (2004), Employment protection and gross job flows: a differences-in-differences approach, mimeograph, World Bank

Pagano M. and P. F Volpin (2005) Managers, Workers, and Corporate Control, The Journal of Finance, 60 (2) , 841-868

Pissarides, C. (2001). Employment protection, Labour Economics, 8, 131-59.

Poschke, M. (2007), Employment protection, firm selection, and growth, IZA Discussion Paper.

Rajan, R., and L. Zingales, (1995), What Do We Know about Capital Structure? Some Evidence from International Data, Journal of Finance. 47, 1367-1400.

Rajan, R., and L. Zingales (1998), Financial Dependence and Growth, American Economic Review, 88, 559-586.

Riphahn, R. (2005), Employment protection and effort among German employees, Economics Letters, 85, 353-357.

Rendon, S., (2004), Job Creation and Investment in Imperfect Capital and Labour Markets. centrA, Documento de Trabajo, E2004/35.

Rogerson, Richard (2008). "Structural Transformation and the Deterioration of European Labor Market Outcomes," Journal of Political Economy, vol. 116(2), pages 235-259

Saint-Paul, G. (2002), Employment Protection, International Specialization, and Innovation, European Economic Review, vol. 46, no. 2, pp. 375-395.

Samaniego, R. (2006), Employment protection and high-tech aversion, Review of Economic Dynamics, 9(2), 224-241.

Scarpetta, S. and T. Tressel (2004), Boosting Productivity via Innovation and Adoption of New Technologies: Any Role for Labour Market Institutions?, World Bank Working Paper No. 3273

Wasmer, E. (2006), General versus Specific Skills in Labour Markets with Search Frictions and Firing Costs, American Economic Review, vol. 96, no. 3, pp. 811-831.

Wasmer, E., Weil, P., (2004). The Macroeconomics of Labour and Credit Market Imperfections. American Economic Review, 94(4), pp. 944-963. 


\begin{tabular}{lccccc} 
& \multicolumn{2}{c}{ Low Job Reallocation } & \multicolumn{2}{c}{ High Job Reallocation } & Diff-in-diff \\
& Low EPL & High EPL & Low EPL & High EPL & \\
$J R$ & 0,122 & 0,149 & 0,144 & 0,169 & $-0,00168$ \\
& $(0,23)$ & $(0,229)$ & $(0,224)$ & $(0,241)$ & {$[0,00167]$} \\
$I / L$ & 1,799 & 1,933 & 1,716 & 1,950 & 0,1005 \\
& $(0,764)$ & $(0,793)$ & $(0,728)$ & $(0,804)$ & {$[0,0073]$} \\
$K / L$ & 2,906 & 2,904 & 2,624 & 2,646 & 0,0225 \\
& $(1,08)$ & $(1,052)$ & $(1,063)$ & $(1,106)$ & {$[0,0078]$} \\
$V A / L$ & 3,293 & 3,346 & 3,451 & 3,380 & $-0,1238$ \\
& $(0,752)$ & $(0,56)$ & $(0,673)$ & $(0,521)$ & {$[0,0053]$} \\
& & & & & \\
\hline
\end{tabular}

Note: High EPL countries are those above the $75^{\text {th }}$ percentile of the sample distribution: Greece, Portugal, Italy (1997) and Spain (1997-2000). Low EPL countries are those below the $25^{\text {th }}$ percentile of the sample distribution: the Czech Republic, Denmark, Finland, Italy (2001-2003), the Netherlands, Poland and the United Kingdom. Similarly, low (high) job reallocation sectors those below (above) the $25^{\text {th }}\left(75^{\text {th }}\right)$ percentile of the distribution of the frictionless job reallocation. At the 2-digit level, industries that account for more than $50 \%$ of observations in high job-reallocation industries at the 4-digit level include: Construction; Collection, purification and distribution of water; Manufacture of radio, television and communication equipment; Land transport; Post and telecommunications; Computer and related activities. Low job reallocation industries include: Extraction of crude petroleum and natural gas; Manufacture of wearing apparel; Recycling; Forestry, logging and related service activities; Air transport; Manufacture of motor vehicles, trailers and semi-trailers. Standard deviations in parentheses. Standard errors in square brackets. 
(1)

(2)

(3)

(4)

(5)

\begin{tabular}{|c|c|c|c|c|c|}
\hline \multirow[t]{2}{*}{ EPL } & 0.065 & - & - & - & - \\
\hline & $(0.029) * *$ & - & - & - & - \\
\hline \multirow{2}{*}{$\begin{array}{l}\text { EPL } \times \\
\text { Benchflow }\end{array}$} & -0.376 & -0.391 & -0.453 & -0.440 & -1.231 \\
\hline & $(0.132)^{* * *}$ & $(0.121)^{* * *}$ & $(0.007)^{* * *}$ & $(0.120)^{* * *}$ & $(0.188)^{* * *}$ \\
\hline Observations & 2040236 & 2040236 & 2040241 & 30411 & 1885882 \\
\hline R-squared & 0.25 & 0.25 & 0.25 & 0.89 & 0.26 \\
\hline Sector FE & YES & - & - & - & - \\
\hline Country FE & YES & - & - & - & - \\
\hline Year FE & YES & - & - & - & - \\
\hline Sector $\times$ Year & NO & YES & YES & YES & YES \\
\hline Country $\times$ Year & NO & YES & YES & YES & YES \\
\hline Controls & NO & NO & YES & NO & NO \\
\hline $\begin{array}{l}\text { Level of } \\
\text { aggregation }\end{array}$ & Firm & Firm & Firm & Sector & Firm \\
\hline $\begin{array}{l}\text { Proxy for } \\
\text { Benchflow }\end{array}$ & $\begin{array}{c}\text { Ciccone- } \\
\text { Papaioannou } \\
(2007)\end{array}$ & $\begin{array}{c}\text { Ciccone- } \\
\text { Papaioannou } \\
(2007)\end{array}$ & $\begin{array}{c}\text { Ciccone- } \\
\text { Papaioannou } \\
(2007)\end{array}$ & $\begin{array}{c}\text { Ciccone- } \\
\text { Papaioannou } \\
(2007)\end{array}$ & $\begin{array}{l}\text { UK job } \\
\text { reallocation }\end{array}$ \\
\hline
\end{tabular}

Robust standard errors in parentheses. clustered at the country-sector-year except in column 4. Additional controls are firm size, number of subsidiaries and exports. * significant at $10 \%$; ** significant at 5\%; *** significant at $1 \%$ 
EPL $x$

benchflow

Observations

R-squared

Sector FE

Country FE

Year FE

Sector $\times$ Year

Country $x$

Year

Controls

Level of

aggregation

Proxy for

Benchflow
(1)

$$
0.014
$$

(0.025)

(2)

$$
\begin{gathered}
-0.207 \\
(0.083)^{* *}
\end{gathered}
$$

1735230

0.12

YES

YES

YES

NO

NO

NO

Firm

Ciccone-

Papaioannou

(2007)
(3)

(4)

(5)

$-0.541$

$-0.220$

$-0.264$

$-0.131$

$(0.113)^{* * *}$

$(0.063)^{* * *}$

1605400

1735230

0.12

1735217

0.12

28778

0.83

0.12

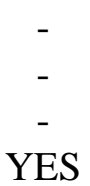

-

YES

YES

YES

YES

YES

YES

NO

NO

Firm

Sector

Firm

Firm

Ciccone-

Ciccone-

Papaioannou

Papaioannou

Ciccone-

(2007)

(2007)

Papaioannou

(2007)

UK job

reallocation

Robust standard errors in parentheses. clustered at the country-sector-year except in column 4. Additional controls are firm size, number of subsidiaries and exports. * significant at $10 \%$; ** significant at 5\%; *** significant at $1 \%$ 
(1)

(2)

\subsection{5}

$(0.022)^{* * *}$

EPL $x$

Benchflow

Observations

R-squared

Sector FE

Country FE

Year FE

Sector $\times$ Year

Country $\times$ Year

Controls

Level of

aggregation

Proxy for

Benchflow

$$
-0.269
$$

$$
(0.110)^{* *}
$$

\begin{abstract}
1574996
\end{abstract}
0.18

YES

YES

YES

NO

NO

NO

Firm

Ciccone-

Papaioannou
$-0.279$

$(0.106)^{* * *}$

$-0.269$

$(0.106)^{* *}$

$-0.273$

$-1.488$

1574996
0.18

1575011

0.18

$(0.102)^{* * *}$

$(0.155)^{* * *}$

(2007)

\section{$-$}

YES

YES

NO

Firm

Ciccone-

Papaioannou

(2007)
26716

0.79

1447989

0.18

\section{)}

(4)

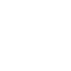

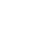


(1)

(2)

$$
\begin{gathered}
0.015 \\
(0.003)^{* * *}
\end{gathered}
$$

EPL $x$

Benchflow

$$
\begin{gathered}
-0.052 \\
(0.016)^{* * *}
\end{gathered}
$$$$
-0.044
$$$$
(0.011)^{* * *}
$$

(4)

Observations

R-squared

$$
2177727
$$

0.03

2177727
0.06

YES

Sector FE

Country FE

Year FE

Sector $\times$ Year

Country $x$

Year

Controls

Level of

aggregation

Proxy for

Benchflow
YES

YES

NO

NO

NO

Firm

Ciccone-

Papaioannou (2007)
0.06

0.06

30665

0.86

0.06

$-0.002$

(0.019)

$(0.011)^{* * *} \quad(0.012)^{* * *}$

\section{7}

.

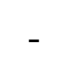

$-$

YES

YES

YES

YES

NO

NO

\footnotetext{
Robust standard errors in parentheses. clustered at the country-sector-year except in column 4. Additional controls are firm size, number of subsidiaries and exports. * significant at $10 \%$; ** significant at $5 \% ; * * *$ significant at $1 \%$
} 
(1)

(2)

(3)

(4)

(5)

(6)

\begin{tabular}{|c|c|c|c|c|c|c|}
\hline EPL & - & 0.021 & - & - & - & - \\
\hline & - & $(0.005)^{* * *}$ & - & - & - & - \\
\hline $\mathrm{EPL} \times \mathrm{BF}$ & $\begin{array}{c}-0.260 \\
(0.057)^{* * *}\end{array}$ & $\begin{array}{c}-0.446 \\
(0.116)^{* * *}\end{array}$ & $\begin{array}{c}-0.318 \\
(0.116)^{* * *}\end{array}$ & $\begin{array}{c}-0.327 \\
(0.116)^{* * *}\end{array}$ & $\begin{array}{c}-0.322 \\
(0.115)^{* * *}\end{array}$ & $\begin{array}{c}-1.320 \\
(0.226)^{* * *}\end{array}$ \\
\hline $\begin{array}{l}\text { Internal } \\
\text { Resources }\end{array}$ & -0.238 & 0.034 & 0.033 & 0.018 & 0.035 & 0.052 \\
\hline ROA & $\begin{array}{c}(0.004)^{* * *} \\
1.055 \\
(0.009)^{* * *}\end{array}$ & $\begin{array}{c}(0.002)^{* * *} \\
-0.090 \\
(0.005)^{* * *}\end{array}$ & $\begin{array}{c}(0.002)^{* * *} \\
-0.102 \\
(0.005)^{* * *}\end{array}$ & $\begin{array}{c}(0.001)^{* * *} \\
-0.001 \\
(0.004)\end{array}$ & $\begin{array}{c}(0.002)^{* * *} \\
-0.099 \\
(0.005)^{* * *}\end{array}$ & $\begin{array}{c}(0.010)^{* * * *} \\
-0.101 \\
(0.006)^{* * *}\end{array}$ \\
\hline $\begin{array}{l}\text { EPL } \times \\
\text { Internal } \\
\text { Resources }\end{array}$ & 0.014 & -0.003 & -0.004 & -0.006 & -0.004 & -0.012 \\
\hline $\begin{array}{l}\mathrm{BF} \times \\
\text { Internal } \\
\text { Resources }\end{array}$ & $\begin{array}{c}0.742 \\
(0.100) * * *\end{array}$ & $\begin{array}{c}-0.176 \\
(0.060) * * *\end{array}$ & $\begin{array}{c}-0.198 \\
(0.060)^{* * *}\end{array}$ & $\begin{array}{c}-0.113 \\
(0.040)^{* * *}\end{array}$ & $\begin{array}{c}-0.202 \\
(0.061)^{* * *}\end{array}$ & $\begin{array}{c}-0.209 \\
(0.086) * *\end{array}$ \\
\hline $\begin{array}{l}\mathrm{EPL} \times \mathrm{BF} \times \\
\text { Internal } \\
\text { Resources }\end{array}$ & $\begin{array}{c}-0.201 \\
(0.038)^{* * *}\end{array}$ & $\begin{array}{c}0.065 \\
(0.023)^{* * *}\end{array}$ & $\begin{array}{c}0.077 \\
(0.023)^{* * *}\end{array}$ & $\begin{array}{c}0.056 \\
(0.015)^{* * *}\end{array}$ & $\begin{array}{c}0.079 \\
(0.023)^{* * *}\end{array}$ & $\begin{array}{c}0.090 \\
(0.034)^{* * *}\end{array}$ \\
\hline $\begin{array}{l}\text { Observations } \\
\text { R-squared }\end{array}$ & $\begin{array}{c}2040236 \\
0.28\end{array}$ & $\begin{array}{c}2040236 \\
0.13\end{array}$ & $\begin{array}{c}2040236 \\
0.15\end{array}$ & $\begin{array}{c}2039972 \\
0.14\end{array}$ & $\begin{array}{c}2040223 \\
0.15\end{array}$ & $\begin{array}{c}1885882 \\
0.14\end{array}$ \\
\hline Year FE & YES & YES & - & - & - & - \\
\hline $\begin{array}{l}\text { Country } \times \\
\text { Year }\end{array}$ & YES & NO & YES & YES & YES & YES \\
\hline $\begin{array}{l}\text { Sector } \times \\
\text { Year }\end{array}$ & YES & NO & NO & NO & NO & NO \\
\hline Firm FE & NO & YES & YES & YES & YES & YES \\
\hline Controls & NO & NO & NO & NO & YES & $\mathrm{NO}$ \\
\hline $\begin{array}{l}\text { Proxy for } \\
\text { Benchflow }\end{array}$ & $\begin{array}{c}\text { Ciccone- } \\
\text { Papaioannou } \\
(2007)\end{array}$ & $\begin{array}{c}\text { Ciccone- } \\
\text { Papaioannou } \\
(2007)\end{array}$ & $\begin{array}{c}\text { Ciccone- } \\
\text { Papaioannou } \\
(2007)\end{array}$ & $\begin{array}{c}\text { Ciccone- } \\
\text { Papaioannou } \\
(2007)\end{array}$ & $\begin{array}{c}\text { Ciccone- } \\
\text { Papaioannou } \\
(2007)\end{array}$ & $\begin{array}{l}\text { UK job } \\
\text { reallocation }\end{array}$ \\
\hline $\begin{array}{l}\text { Proxy for } \\
\text { internal } \\
\text { resources }\end{array}$ & Cash flow & Cash flow & Cash flow & $\begin{array}{l}\text { Net Liquid } \\
\text { Assets }\end{array}$ & Cash flow & Cash flow \\
\hline
\end{tabular}

Robust standard errors in parentheses. clustered at the firm-level. Additional controls are firm size, number of subsidiaries and exports. * significant at $10 \%$; ** significant at $5 \%$; *** significant at $1 \%$ 
EPL

$\mathrm{EPL} \times \mathrm{BF}$

Internal

Resources

ROA

EPL $x$

Internal

Resources

$\mathrm{BF} \times$

Internal

Resources

$\mathrm{EPL} \times \mathrm{BF} \times$

Internal

Resources

Observations

$\mathrm{R}$-squared

Year FE

Country $x$

Year

Sector $X$

Year

Firm FE

Controls

Proxy for

Benchflow

Proxy for internal resources

$$
(0.001)^{* * *}
$$

$$
(0.001) * * *
$$

$$
0.042
$$

0.086

0.068

$-0.045$

$-0.037$

$-0.029$

$$
(0.028)
$$

$(0.031)$

1735230
0.12
YES
YES
YES
NO
NO

1735230

0.01

\section{YES}

NO

YES

NO

NO

YES

YES
(2007) (2007) (2007) Cash flow

Cash flow Cash flow
(1)

(2)

(3)

$-0.024$

$(0.006) * * *$

-0.199
$(0.046)^{* * *}$

0.304

$(0.164)^{*}$

0.157

(0.161)

$-0.026$

$-0.025$

$(0.003) * * *$

0.132

$(0.003)^{* * *}$

0.129

$(0.010)^{* * *}$

$(0.008) * * *$

$(0.010)^{* * *}$

0.011

0.011

(4)

(5)

(6)

$(0.001)^{* * *}$

$(0.001)^{* * *}$

$(0.001)^{* * *}$

$(0.005)^{* *}$

$-0.101$

0.057

$-0.047$

$\begin{array}{lllll}(0.075) & (0.084) & (0.083) & (0.046)^{* *} & (0.084)\end{array} \quad(0.120)$

0.032

$-0.025$

$-0.027$

$(0.031)$

$(0.018)^{*}$

(0.032)

$(0.046)$
1735230
0.02
1735049
0.02
1735210
0.02

1605400

YES

YES

YES

NO

NO

NO

YES

YES

YES

YES

NO

Ciccone- Ciccone- Ciccone- Ciccone- CicconePapaioannou Papaioannou Papaioannou Papaioannou Papaioannou

(2007)

(2007) $\mathrm{UK}$ job
reallocation

Net Liquid Assets

Cash flow Cash flow

Robust standard errors in parentheses. clustered at the firm-level. Additional controls are firm size, number of subsidiaries and exports. * significant at $10 \%$; ** significant at $5 \%$; *** significant at $1 \%$ 
(1)

(2)

(3)

(4)

(5)

(6)

\begin{tabular}{|c|c|c|c|c|c|c|}
\hline \multirow{2}{*}{ EPL } & - & 0.172 & - & - & - & - \\
\hline & - & $(0.003)^{* * *}$ & - & - & - & - \\
\hline \multirow[t]{2}{*}{$\mathrm{EPL} \times \mathrm{BF}$} & -0.241 & -0.014 & 0.003 & -0.007 & 0.001 & -0.460 \\
\hline & $(0.035) * * *$ & $(0.064)$ & (0.064) & $(0.064)$ & $(0.063)$ & $(0.120) * * *$ \\
\hline \multirow{2}{*}{$\begin{array}{l}\text { Internal } \\
\text { Resources }\end{array}$} & 0.014 & -0.012 & -0.012 & -0.018 & -0.010 & 0.007 \\
\hline & $(0.003)^{* * *}$ & $(0.002)^{* * *}$ & $(0.002)^{* * *}$ & $(0.001)^{* * *}$ & $(0.002)^{* * *}$ & $(0.010)$ \\
\hline ROA & $\begin{array}{c}0.798 \\
(0.006)^{* * *}\end{array}$ & $\begin{array}{c}0.018 \\
(0.005)^{* * *}\end{array}$ & $\begin{array}{c}0.019 \\
(0.005)^{* * *}\end{array}$ & $\begin{array}{c}0.004 \\
(0.004)\end{array}$ & $\begin{array}{c}0.021 \\
(0.005)^{* * *}\end{array}$ & $\begin{array}{c}0.017 \\
(0.005)^{* * *}\end{array}$ \\
\hline \multirow{2}{*}{$\begin{array}{l}\text { EPL } \times \\
\text { Internal } \\
\text { Resources }\end{array}$} & 0.003 & 0.003 & 0.002 & 0.005 & 0.001 & -0.005 \\
\hline & $(0.001)^{* * *}$ & $(0.001)^{* * *}$ & $(0.001)^{* *}$ & $(0.000)^{* * *}$ & $(0.001)^{*}$ & (0.004) \\
\hline \multirow[t]{2}{*}{$\begin{array}{l}\mathrm{BF} \times \\
\text { Internal } \\
\text { Resources }\end{array}$} & 0.032 & -0.044 & -0.024 & -0.016 & -0.024 & -0.168 \\
\hline & $(0.072)$ & $(0.061)$ & $(0.060)$ & $(0.029)$ & $(0.061)$ & $(0.087)^{*}$ \\
\hline \multirow{2}{*}{$\begin{array}{l}\mathrm{EPL} \times \mathrm{BF} \times \\
\text { Internal } \\
\text { Resources }\end{array}$} & -0.071 & 0.016 & 0.010 & 0.004 & 0.010 & 0.063 \\
\hline & $(0.026) * * *$ & $(0.022)$ & $(0.022)$ & $(0.011)$ & $(0.022)$ & $(0.033)^{*}$ \\
\hline Observations & 1574996 & 1574996 & 1574996 & 1574750 & 1575000 & 1447989 \\
\hline R-squared & 0.22 & 0.02 & 0.04 & 0.04 & 0.05 & 0.04 \\
\hline Year FE & YES & YES & - & - & - & - \\
\hline $\begin{array}{l}\text { Country } \times \\
\text { Year }\end{array}$ & YES & NO & YES & YES & YES & YES \\
\hline $\begin{array}{l}\text { Sector } \times \\
\text { Year }\end{array}$ & YES & NO & $\mathrm{NO}$ & NO & NO & $\mathrm{NO}$ \\
\hline Firm FE & NO & YES & YES & YES & YES & YES \\
\hline Controls & NO & NO & NO & $\mathrm{NO}$ & YES & NO \\
\hline $\begin{array}{l}\text { Proxy for } \\
\text { Benchflow }\end{array}$ & $\begin{array}{c}\text { Ciccone- } \\
\text { Papaioannou } \\
\text { (2007) }\end{array}$ & $\begin{array}{c}\text { Ciccone- } \\
\text { Papaioannou } \\
\text { (2007) }\end{array}$ & $\begin{array}{c}\text { Ciccone- } \\
\text { Papaioannou } \\
(2007)\end{array}$ & $\begin{array}{c}\text { Ciccone- } \\
\text { Papaioannou } \\
\text { (2007) }\end{array}$ & $\begin{array}{c}\text { Ciccone- } \\
\text { Papaioannou } \\
(2007)\end{array}$ & $\begin{array}{l}\text { UK job } \\
\text { reallocation }\end{array}$ \\
\hline $\begin{array}{l}\text { Proxy for } \\
\text { internal } \\
\text { resources }\end{array}$ & Cash flow & Cash flow & Cash flow & $\begin{array}{l}\text { Net Liquid } \\
\text { Assets }\end{array}$ & Cash flow & Cash flow \\
\hline
\end{tabular}

Robust standard errors in parentheses. clustered at the firm-level. Additional controls are firm size, number of subsidiaries and exports. * significant at $10 \%$; ** significant at $5 \%$; *** significant at $1 \%$ 
(1)

(2)
(3)
(4)

(5)

(6)

\begin{tabular}{|c|c|c|c|c|c|c|}
\hline EPL & & $\begin{array}{c}0.006 \\
(0.001)^{* * * *}\end{array}$ & & $\begin{array}{l}- \\
-\end{array}$ & $\begin{array}{l}- \\
-\end{array}$ & $\begin{array}{l}- \\
-\end{array}$ \\
\hline $\mathrm{EPL} \times \mathrm{BF}$ & $\begin{array}{c}-0.048 \\
(0.008)^{* * *}\end{array}$ & $\begin{array}{c}0.022 \\
(0.034)\end{array}$ & $\begin{array}{c}0.025 \\
(0.033)\end{array}$ & $\begin{array}{c}0.016 \\
(0.034)\end{array}$ & $\begin{array}{c}0.025 \\
(0.033)\end{array}$ & $\begin{array}{c}0.024 \\
(0.065)\end{array}$ \\
\hline $\begin{array}{l}\text { Internal } \\
\text { Resources }\end{array}$ & 0.004 & -0.001 & -0.001 & -0.001 & -0.001 & -0.007 \\
\hline ROA & $\begin{array}{c}(0.001)^{* * * *} \\
-0.083 \\
(0.002)^{* * *}\end{array}$ & $\begin{array}{c}(0.001) \\
-0.047 \\
(0.003)^{* * *}\end{array}$ & $\begin{array}{c}(0.001) \\
-0.048 \\
(0.003)^{* * *}\end{array}$ & $\begin{array}{c}(0.000)^{*} \\
-0.041 \\
(0.002)^{* * *}\end{array}$ & $\begin{array}{c}(0.001) \\
-0.048 \\
(0.003)^{* * *}\end{array}$ & $\begin{array}{c}(0.004)^{*} \\
-0.047 \\
(0.003)^{* * *}\end{array}$ \\
\hline $\begin{array}{l}\text { EPL } \times \\
\text { Internal } \\
\text { Resources }\end{array}$ & $\begin{array}{l}-0.000 \\
(0.000)\end{array}$ & $\begin{array}{c}0.001 \\
(0.000)^{* *}\end{array}$ & $\begin{array}{c}0.001 \\
(0.000)^{* *}\end{array}$ & $\begin{array}{c}0.000 \\
(0.000)\end{array}$ & $\begin{array}{c}0.001 \\
(0.000)^{* *}\end{array}$ & $\begin{array}{c}0.003 \\
(0.001)^{*}\end{array}$ \\
\hline $\begin{array}{l}\mathrm{BF} \times \\
\text { Internal } \\
\text { Resources }\end{array}$ & $\begin{array}{l}-0.023 \\
(0.015)\end{array}$ & $\begin{array}{l}-0.009 \\
(0.023)\end{array}$ & $\begin{array}{l}-0.008 \\
(0.023)\end{array}$ & $\begin{array}{c}-0.026 \\
(0.012)^{* *}\end{array}$ & $\begin{array}{l}-0.008 \\
(0.023)\end{array}$ & $\begin{array}{l}0.050 \\
(0.032)\end{array}$ \\
\hline $\begin{array}{l}\text { EPL } \times \text { BF } \times \\
\text { Internal } \\
\text { Resources }\end{array}$ & $\begin{array}{c}0.007 \\
(0.006)\end{array}$ & $\begin{array}{c}0.004 \\
(0.009)\end{array}$ & $\begin{array}{l}0.004 \\
(0.009)\end{array}$ & $\begin{array}{c}0.011 \\
(0.005)^{* *}\end{array}$ & $\begin{array}{c}0.004 \\
(0.009)\end{array}$ & $\begin{array}{l}-0.017 \\
(0.013)\end{array}$ \\
\hline $\begin{array}{l}\text { Observations } \\
\text { R-squared }\end{array}$ & $\begin{array}{c}2177727 \\
0.07\end{array}$ & $\begin{array}{c}2177727 \\
0.00\end{array}$ & $\begin{array}{c}2177727 \\
0.06\end{array}$ & $\begin{array}{c}2177439 \\
0.06\end{array}$ & $\begin{array}{c}2177735 \\
0.06\end{array}$ & $\begin{array}{c}2014307 \\
0.05\end{array}$ \\
\hline Year FE & YES & YES & - & - & - & - \\
\hline $\begin{array}{l}\text { Country } \times \\
\text { Year }\end{array}$ & YES & NO & YES & YES & YES & YES \\
\hline $\begin{array}{l}\text { Sector } \times \\
\text { Year }\end{array}$ & YES & NO & NO & NO & $\mathrm{NO}$ & NO \\
\hline Firm FE & NO & YES & YES & YES & $\begin{array}{l}\text { YES } \\
\text { YES }\end{array}$ & YES \\
\hline Controls & NO & NO & $\mathrm{NO}$ & NO & YES & NO \\
\hline $\begin{array}{l}\text { Proxy for } \\
\text { Benchflow }\end{array}$ & $\begin{array}{c}\text { Ciccone- } \\
\text { Papaioannou } \\
(2007)\end{array}$ & $\begin{array}{c}\text { Ciccone- } \\
\text { Papaioannou } \\
(2007)\end{array}$ & $\begin{array}{c}\text { Ciccone- } \\
\text { Papaioannou } \\
(2007)\end{array}$ & $\begin{array}{c}\text { Ciccone- } \\
\text { Papaioannou } \\
(2007)\end{array}$ & $\begin{array}{c}\text { Ciccone- } \\
\text { Papaioannou } \\
(2007)\end{array}$ & $\begin{array}{l}\text { UK job } \\
\text { reallocation }\end{array}$ \\
\hline $\begin{array}{l}\text { Proxy for } \\
\text { internal } \\
\text { resources }\end{array}$ & Cash flow & Cash flow & Cash flow & $\begin{array}{l}\text { Net Liquid } \\
\text { Assets }\end{array}$ & Cash flow & Cash flow \\
\hline
\end{tabular}

Robust standard errors in parentheses. clustered at the firm-level. Additional controls are firm size, number of subsidiaries and exports. * significant at $10 \%$; ** significant at $5 \%$; *** significant at $1 \%$ 